\title{
44. MESOZOIC EVOLUTION OF WESTERN NORTH ATLANTIC AND NORTH TETHYAN MARGINS: A COMPARISON
}

\author{
Maurice Bourbon, Centre de Recherches de Géologie Generale, Ecole des Mines, Paris, France
}

\section{INTRODUCTION: PURPOSE AND LIMITATIONS}

As Bernoulli (1972) and Bernoulli and Jenkyns (1974) have shown, the Mesozoic facies of the western North Atlantic margin and those of the Tethyan Sea margins are very similar. In this paper I compare coeval facies and the sedimentary and tectonic evolution of both margins. My approach to the problem is not a narrow view; both groups of sediments have different features and must be studied in different ways, but the comparison is interesting because the study of both areas are complementary and enrich one another.

The Atlantic sediments are from DSDP Holes 390, 391, and 392 (Figure 1). They are very well preserved and are neither greatly altered nor metamorphosed and they have not been subjected to tectonism. Moreover, their vertical succession is usually undisturbed and their approximate lateral extent and characteristics can be determined from seismic profiles. On the other side, the Alpine sedimentary rocks are always folded - often extensively, and are sometimes more or less metamorphosed. The continuity of an Alpine sequence is sometimes interrupted by thrusts or faults. Although in the higher altitudes - as is often the case in the Briançonnais mountains - the sedimentary succession is exposed in broad outcrops so that lateral and vertical variations may be easily studied.

Finally, although it may seem strange to compare sediments which were deposited on an oceanic crust (Hole 391C) with those deposited on a continental crust (Briançonnais) such a comparison demonstrates that they share a similar geographic evolution.

Because the Atlantic sediments are only known from drillholes, and also because the main purpose of this paper is to compare the evolution of both sedimentary environments, the Alpine series is described on the basis of certain characteristic sections. Figures showing these sections comprise the main results of the sedimentological analysis. The analyses are also discussed and interpreted in the text.

\section{WESTERN NORTH ATLANTIC MARGIN}

\section{Blake-Bahama Basin (Hole 391C)}

\section{Sedimentological Features}

The lithology and sedimentary characteristics of the Hole $391 \mathrm{C}$ sediments are presented in Figure 2. The sedimentary sequence is divided into lithologic units defined in the Site 391 report (this volume).

The sediments of units 4 and 5 consist mainly of calcareous mudstone, except for the base (sub-unit 5b), which is calcareous claystone, and the top(sub-unit $4 a$ ), which is mostly sand and calcarenite. The calcareous mudstone, often burrowed (Plate 1, Figures 1 and 3), may be the indigenous sediment. The sediment, however, contains several thin layers (often

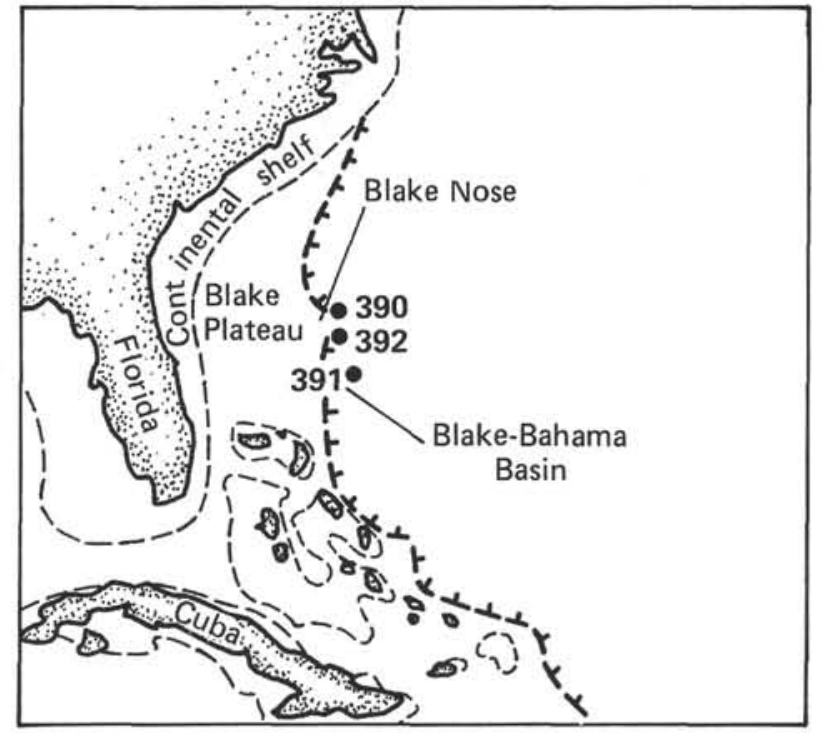

Figure 1. Location of Sites 390, 391, and 392.

100 to $300 \mu \mathrm{m}$ ) of fish-skeletal fragments or radiolarians which proves that the sediment was transported and/or sorted (Plate 2, Figures 1 and 2). The fish skeletal fragments are more common in sub-unit $4 \mathrm{a}$, and the radiolarians are more common in two intervals: the lower Tithonian, and the upper(?) Berriasian-lower Barremian. The frequency curves of organic matter also show maxima during the same intervals. This suggests that these "radiolarenites" were deposited by gravity flows and quickly buried rather than from sorting by bottom currents in which case they would have been oxygenated.

The sediments of unit 3 (Site 391 report, this volume) consist of well bedded claystone and siltstone which are calcareous at the base (3b), and non-calcareous above (3a). This bedding is often regular, particularly in the black clay facies; in some places it is irregular, as in the red facies, and includes pebbles and disturbed contacts (Plate 3, Figures 1 and 2). Most or all of these sediments are allochthonous.

Many layers of metallic micronodules occur in the series (size: 50 to $300 \mu \mathrm{m}$, composition: iron sulfide, pyrrhotite ?). The structure of the micronodules is simple; they are roughly spherical, some are homogeneous, and some have a nucleus (often $\mathrm{CaCO}_{3}$ ) and a cortex (probably FeS). The presence of the uppermost nodule-rich layers, which occur near the sedimentary hiatus between units $4 a$ and $3 b$, suggests that this hiatus could be a "hard-ground."

\section{Clay Mineralogy}

We analyzed too few samples to formulate a solid interpretation. However, the smectite content is high in the upper part of the sequence in the black shale, whereas the kaolinite and 


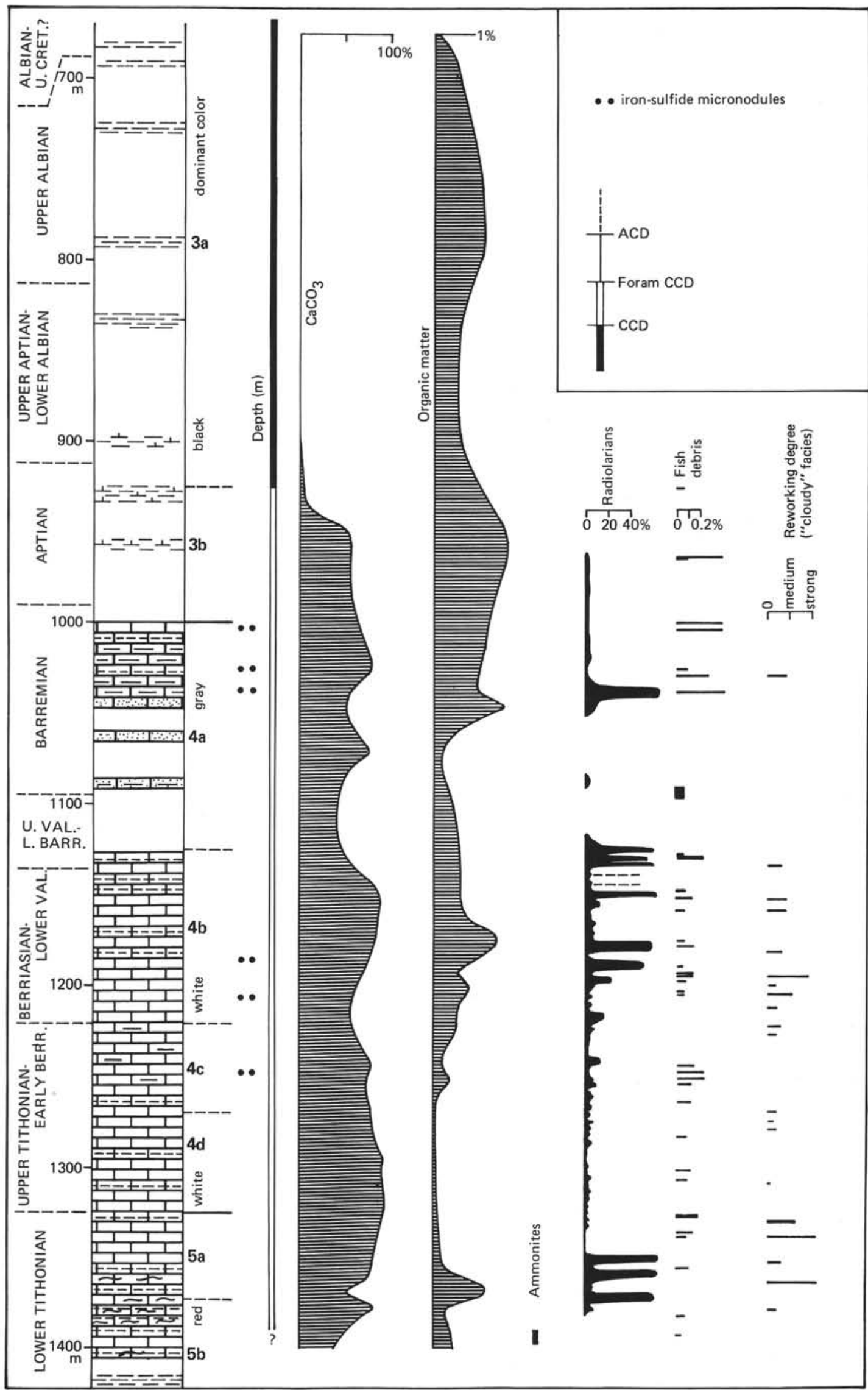

Figure 2. Blake-Bahama Basin (Hole 391C): lithology and some sedimentological characteristics. 
illite contents are low (Figure 3). This could reflect a particular climatic phenomenon which may also have caused the production and deposition of detritic and organic continental material (Deroo et al., this volume). The two low smectite contents occurred in two red beds which had been reworked or burrowed. Either the sediment was autochthonous or it had a detrital supply coming from a completely different source than that of the black shales.

\section{Fauna}

There are no fossils in the uppermost non-calcareous part of the series.

In the calcareous sediments (units $3 b, 4,5$ ), most of the fossils are calcitized radiolarians. No trace of biogenic silica, which was the primary component of the radiolarian tests, has been found in the sediment; it obviously has been removed from these beds. The radiolarians occur either randomly (dispersed in thin sections) or concentrated in layers, where they apparently accumulated following transport and sorting by current activity (bottom currents, contour currents, or gravity flows) (Plate 2, Figures 1 and 2).

Other components of the fauna include

1) a few Aptychus fragments;

2) some pelagic foraminifers in sub-unit $4 a$, as shown by Freeman and Enos (this volume);

3) rarely occurring calpionellids, found in two layers: Sample 391C-45-2, 27-30 cm, with only Calpionella alpina, and Sample 391C-24-4, 68-71 cm, which contains Tintinopsella carpathica and Calpionellopsis simplex (found by Leo Pastouret). These middle or upper Berriasian organisms are obviously reworked into a layer of upper Valanginian-lower Barremian sediment;

4) a few small, elongated, calcareous, straight or curved, monocrystalline, or polycrystalline unidentifiable fragments (pelagic crinoid fragments?, pelagic bivalves?);

5) phosphatic fish debris which also accumulated in millimetric layers (notably in Barremian-Aptian beds; Plate 2, Figure 2); and

6) some ammonites, found during the shipboard examination of the cores.

\section{Depth of Deposition}

The fauna is poor throughout the entire sequence and above all, it is very monotonous. The fauna is almost exclusively composed of siliceous (radiolarians) and phosphatic (fish debris) organisms. This suggests its deposition at a relatively great water depth - below or near the foraminifer carbonate compensation depth. During deposition, the top (sub-unit 3a)was probably below the total carbonate compensation depth (CCD). Determining the deposition depth for the base (sub-unit 5B) is more complex; ammonite shells were found in these beds which suggests that they were deposited above the aragonite compensation depth (ACD). But, on the other hand, Saccocoma are missing, whereas they are abundant in coeval (Lower Tithonian) sediments of Holes 100 and 105 (Leg 11, Bernoulli, 1972; Lancelot et al, 1972); this would indicate that the deposition depth was below the CCD. Thus two solutions are possible: (1) either the ammonites were transported below the ACD and buried more quickly than their speed of dissolution, or (2) the sediments were deposited above the ACD and the Saccocoma are absent for some other unknown reason.

\section{Redox Environment}

White, pinkish, or reddish rock colors indicate primary oxidizing conditions (e.g., Tithonian red clayey limestone and Aptian-Albian variegated clay) and dark colors indicate reducing environments (e.g., the Aptian-Albian black shales). In the case of the black shale, Deroo et al. (this volume) have demonstrated that the organic matter was mainly of detrital origin, derived from continental plants rather than from sapropelic deposits. But, we cannot exclude the possibility that this organic matter was preserved by quick burial in more or less oxidizing conditions on the sea floor.

The thin black beds of the Lower Cretaceous correspond either to brief episodes of stagnation, or to small influxes of detrital sediments, which provided the black material to the black shale.

\section{Temperatures and Salinities}

Because of the complex results of the isotopic analysis, I do not discuss temperatures and salinities here, but recommend that readers refer to the scientific discussion in the companion paper by Létolle et al. (this volume).

\section{Blake Nose (Holes 390, 390A, and 392A)}

The stratigraphy of the Blake Nose from bottom to top is as follows: skelmoldic limestone ( $\sim 90 \mathrm{~m})$; oolitic limestone ( $~$ $30 \mathrm{~m}$ ); fenestral limestone $(\sim 120 \mathrm{~m})$; hard-ground and crust; and pelagic ooze with a predominance of nannofossils $(\sim$ $150 \mathrm{~m}$ from Barremian to middle Eocene). (See also Figure 4.)

The uppermost three units ${ }^{1}$ were deposited in a shallow marine environment with periodical sub-aerial exposures. The sub-aerial exposure is especially reflected in the fenestral limestone where the presence of asymmetric cement proves the vadose conditions and the oolitic limestone was deposited in a highly agitated environment. The fauna of the fenestral limestone is very poor in species and seems to indicate a rather restricted environment. The thickness $(\sim 250 \mathrm{~m})$ and nature (marine and shallow-water) of the sediments suggest that during this period, subsidence was equal to thickness of the deposits.

The top of the fenestral limestone is marked by a thin (few-centimeter) red layer, which is probably rich in iron. The layer was interpreted on board ship as a soil formation, then later as a hard-ground after the discovery of marine organisms during shore-based laboratory work.

The pelagic ooze is characterized by

1) condensation of the section (for example, $40 \mathrm{~m}$ from Barremian to Maestrichtian in Hole 390);

2) gaps in the sedimentary sequence (for example, at the top of the fenestral limestone the hard-ground probably corresponds to a gap in deposition for an unknown interval of time during the Barremian). The upper Albian, Cenomanian, Turonian, Coniacian, and Santonian are not present anywhere. Furthermore, the contact between lower Albian and upper Campanian sediments is perceptible, and sharp, in Hole 390A. The gap seems to be the result of bottom

\footnotetext{
${ }_{1}$ The results concerning these beds come from different sources: (a) the site reports (this volume); (b) Enos and Freeman (this volume); and (c) personal communications with $\mathrm{H}$. Arnaud and A. Arnaud-Vanneau (Institut de Géologie, Grenoble, France).
} 


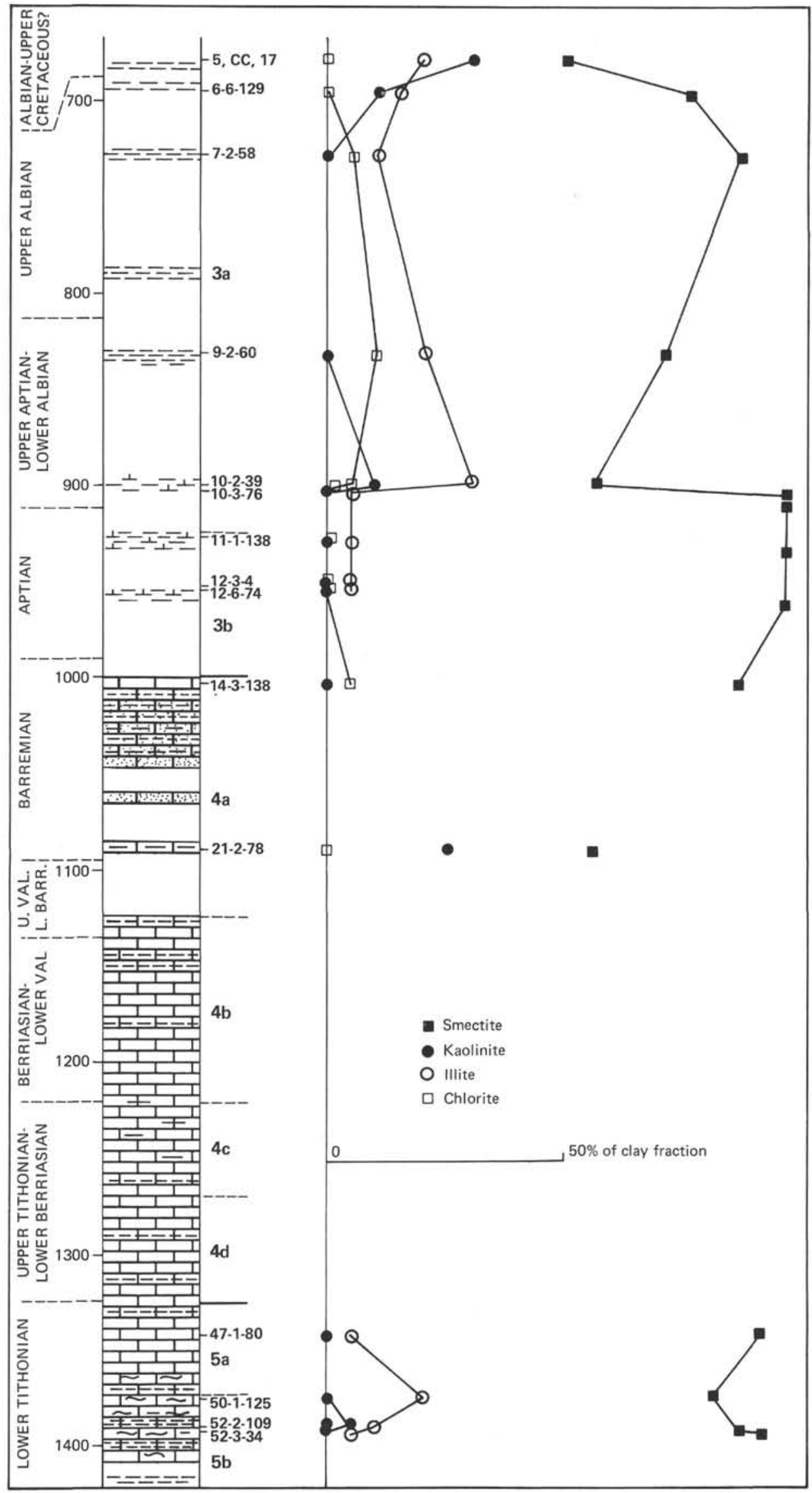

Figure 3. Blake-Bahama Basin: clay mineralogy of some samples. 


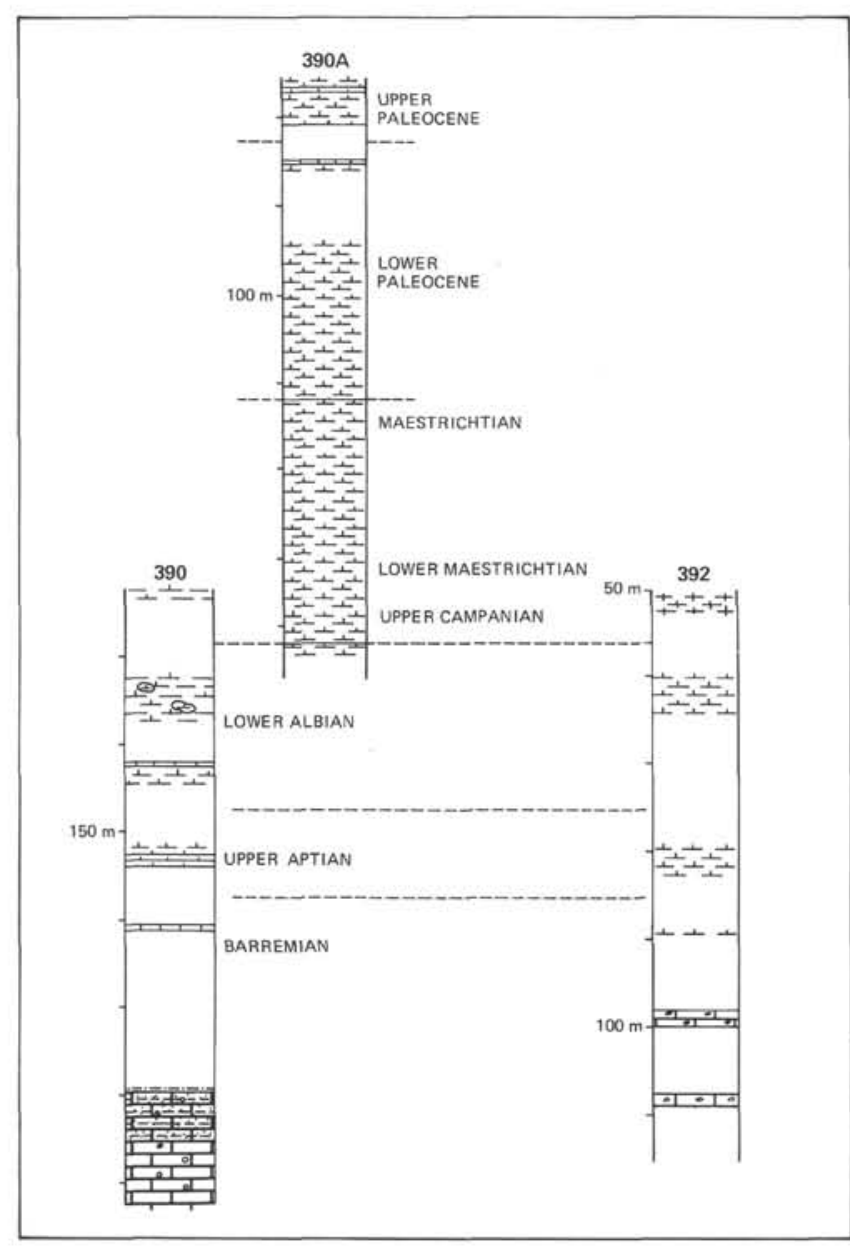

Figure 4. Blake Nose: lithology of Sites 390 and 392.

current activity during upper Albian to lower Campanian times, may be comparable to that has been recorded in Tertiary and Quaternary sediments. Other gaps which are too small to be detected also probably contributed to the condensation of the section.

3) fauna comprised mostly of nannofossils and planktonic foraminifers. Thus the pelagic ooze was deposited in much deeper water than were the uppermost three units, but at somewhat shallower levels than the ACD in the lowest part, which contains ammonites (Barremian part, 392A);

4) a sharp contact, marked by a hard-ground, between the fenestral limestone and the overlying pelagic ooze. This clearly shows a complete change of the sedimentary conditions, especially with regard to water depth. The age of this event could well be Barremian or older. We shall come back to this point later.

\section{NORTH TETHYAN MARGIN}

\section{Introduction: Geological Setting}

A structural sketch of the ancient North Tethyan margin in the Western Alps is given in Figure 5. Figure 6 is a schematic palinspastic transverse section for Late Jurassic time which shows the approximate location of the described sections. From west to east - i.e. trending from the paleocontinent toward the paleo-ocean — we find
1) the Massif Central, an emerged crystalline massif;

2) the Subalpine or Dauphine zone, sensu lato, which comprises various types of sediments - neritic, reefal, benthic, or hemipelagic - depending upon the area; (The Jurassic and Cretaceous sediment is dominantly calcareous, with an important terrigenous contribution from the then nearby continent. The rate of sedimentation was generally high.)

3) the Sub-briançonnais and Briançonnais zones which we group under the same name "Briançonnais s.l." Without a doubt pelagic sediments were deposited in this region during Jurassic-Cretaceous times. The sediments are dominantly calcareous, and were deposited in deeper water on shifting unsteady bottoms. The rate of sedimentation was much lower than in the and subalpine zone.

4) Prèpiémont and Piémont zones which we call here "Piémont s.l." The sediments were deposited on a continental crust (west) and on an oceanic crust (east) from the Late Jurassic onwards. Unfortunately, extensive Alpine metamorphism makes sedimentologic study of these sediments very difficult. The depositional environment must have been deep water; directly above the Upper Jurassic ophiolites we find manganiferous radiolarite and limestone, overlain by Lower Cretaceous siltstone and calcarenite and, finally, probable Upper Cretaceous flyschs.

The following sections of these different zones show some affinities with the North Atlantic sediments.

\section{Subalpine Zone}

\section{Hemipelagic Facies}

Beaudoin et al. (1975) provided the following data; see also Figure 7.

1) The hemipelagic sediments contain a composite fauna of both pelagic (ammonites, planktonic foraminifers, radiolarians, Saccocoma, calpionellids) and benthic (echinoderms, sponges, benthic foraminifers, gastropods) fossils. Thus, the bottom of the sea probably was at least a few hundred meters deep, but well above the ACD.

2) The sequence has an important terrigenous contribution (clay and silt components of the marly limestone) owing to the proximity of the continent.

3) The sediments were deposited at a high rate: about 10 $\mathrm{mm}$ per 1000 years with a maximum of $18 \mathrm{~mm}$ per 1000 years from the late Oxfordian to the Berriasian; $30 \mathrm{~mm}$ per 1000 years from the Valanginian to the Barremian; and 15 mm per 1000 years from the Aptian to the Campanian. (Compaction is not taken into account.) These high sedimentation rates can be explained by the significant contribution of terrigenous sediments and by the rather shallow depth of deposition.

4) Redox conditions fluctuated; they were reducing in some periods (upper Oxfordian and Aptian-AlbianCenomanian black marls), less reducing in others (Valanginian pyritic marl and slightly blue Hauterivian-Barremian limestone) and somewhat oxidizing in still others (Kimmeridgian hard-ground and Tithonian-Berriasian light colored limestone).

\section{Urgonian Facies}

In certain regions of the Subalpine zone, thick reefal and peri-reefal sediments were deposited during late Hauterivian 


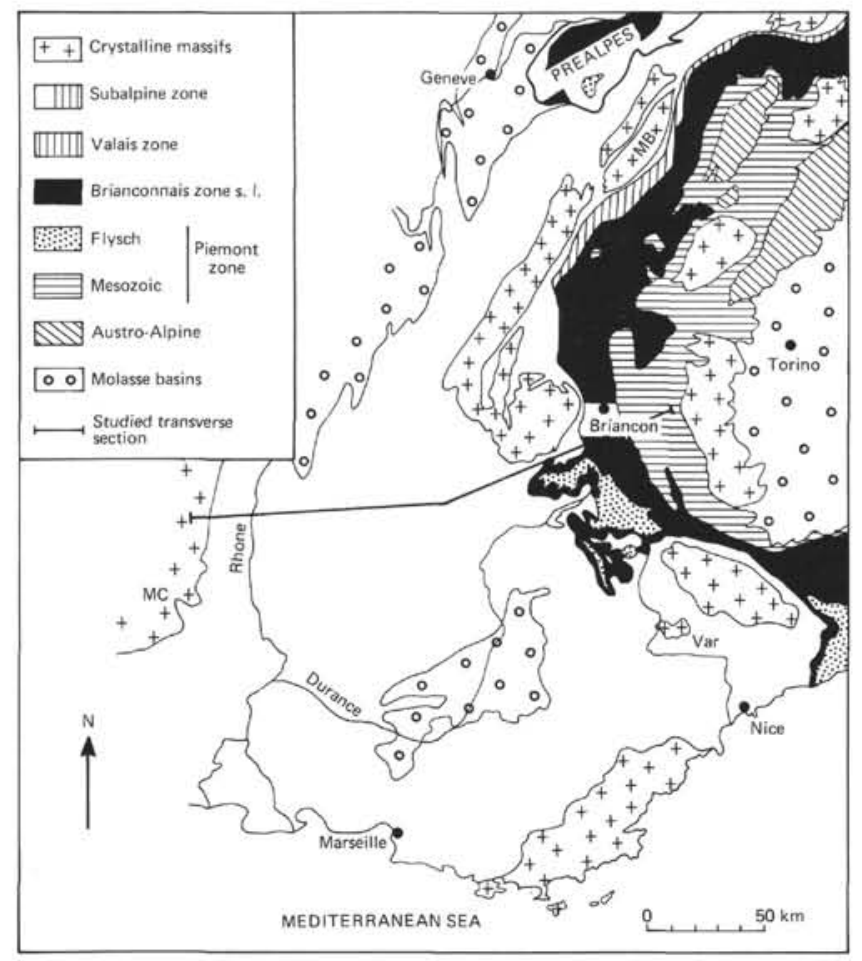

Figure 5. Structural map of the French Western Alps.

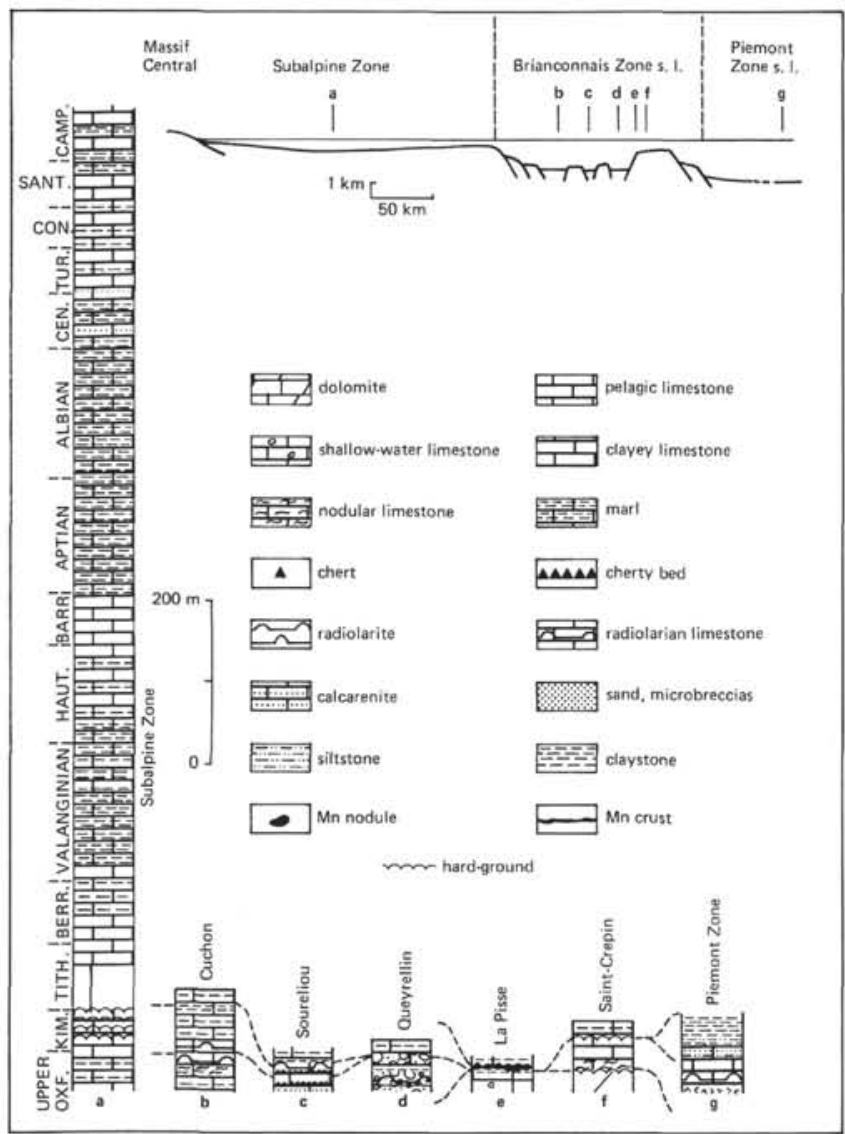

Figure 6. Transverse section of the North-Tethyan margin and summary lithology of the described sections.

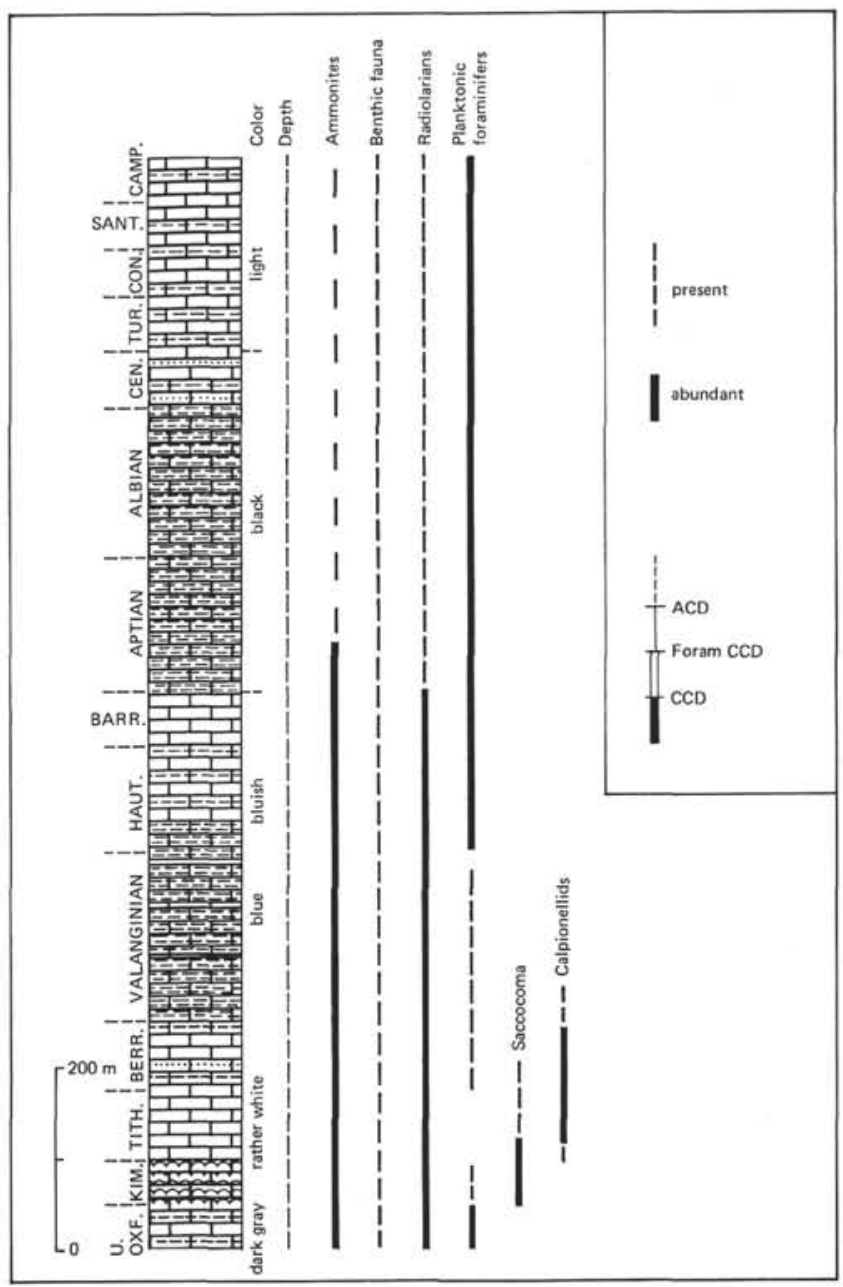

Figure 7. Subalpine zone: a type of section.

and early Barremian times. I do not describe this facies here, but note the similarities of age and facies to the Barremian sediments of the Blake Nose.

\section{Briançonnais Zone}

\section{Introduction: the Briançonnais Mesozoic}

The post-Paleozoic sediments are divided into three main parts: (1) lowermost Triassic continental or shallow-marine quartzites which mark the end of the late Variscan continental Permo-Carboniferous molasse deposition; (2) middle Triassic to Paleocene mainly carbonate or marly marine sediments; and (3) lower-middle Eocene sandstone and siltstone.

The carbonate succession (2) is subdivided into two main marine series (Bourbon et al., 1973, 1975): (2a) thick (500-1500 m) Triassic and lower Liassic platform carbonates deposited in shallow-sea environments; $(2 \mathrm{~b})$ thin or very thin (often less than $100 \mathrm{~m}$ ) Middle Jurassic to Paleocene deeper marine series. The superposed series 2a and $2 \mathrm{~b}$ are separated by a regional, at least cartographic unconformity, and, at some place, by conglomerates with rounded pebbles, or by coal seams and bauxitic layers. These facts all indicate that the whole Briançonnais domain 
was emergent during late Liassic time, whereas the neighboring domains (Dauphinois s.1. on one side, Piémont s.1. on the other side) remained below sea level.

The base of series ( $2 b$ ) comprises either shallow-water carbonate (Middle Jurassic) or pelagic Upper Jurassic limestone. From the Upper Jurassic beds up to the Upper Cretaceous-Paleocene beds, it consists almost entirely of pelagic limestone or clayey limestone - sometimes with chert.

We shall now look at several sections in these series, in order to compare them with the coeval ones of the western North Atlantic margin. The short following descriptions are the commentary to Figures 8 to 10 .

\section{Cuchon Section (Figure 8; P.Y. Chenet, personal com- munication)}

Figure 8 shows that the Cuchon section comprised alternating (1) deep-water indigenous sediments consisting of radiolarites, radiolarian-nannofossil limestone (Plate1, Figure 4; Plate 2, Figures 3,4) and clayey limestone, and (2) allochthonous sediments consisting of calcarenites and silty material (upper Oxfordian, Upper Cretaceous), resedimented nodular limestone (Kimmeridgian-lower Tithonian), breccias and microbreccias (upper OxfordianKimmeridgian; Plate 2, Figure 4), and olistolites (Albian ?-Cenomanian).

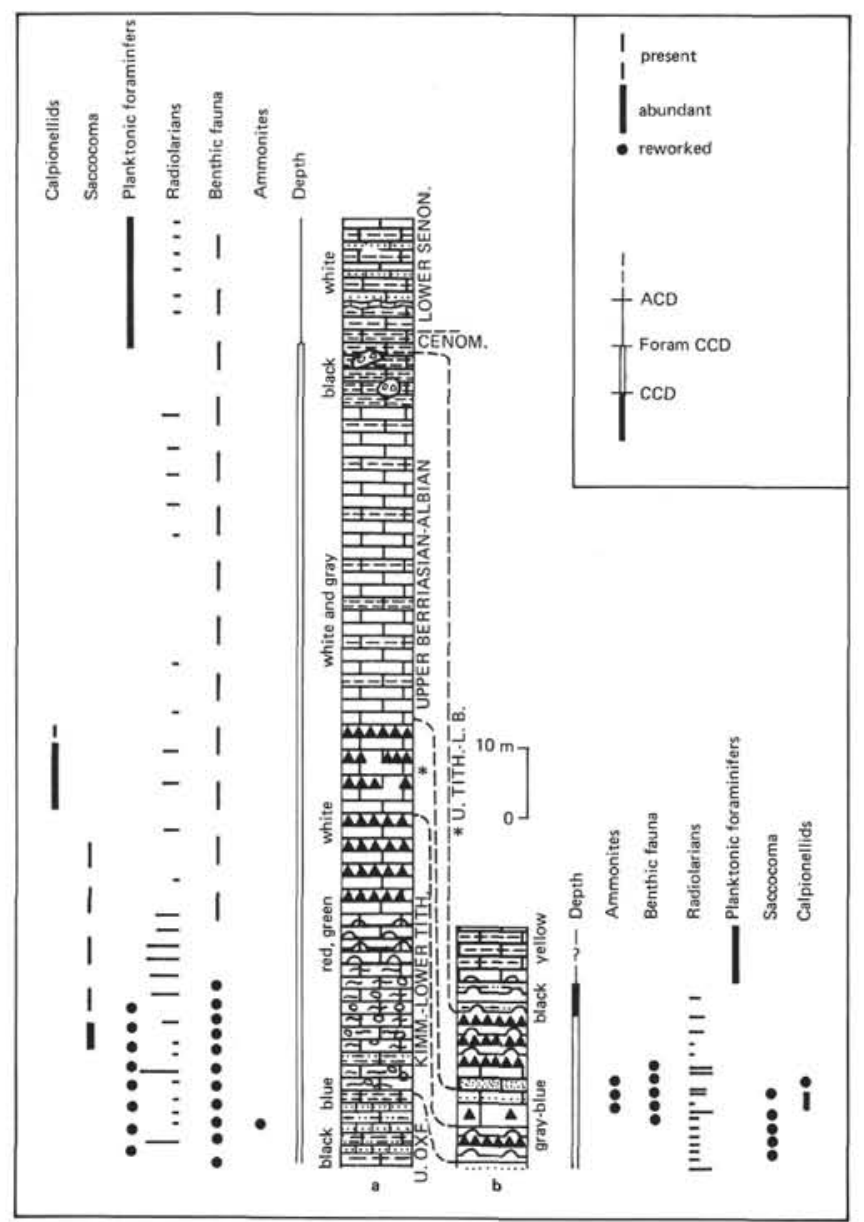

Figure 8. Cuchon (a) and Soureliou (b) sections.

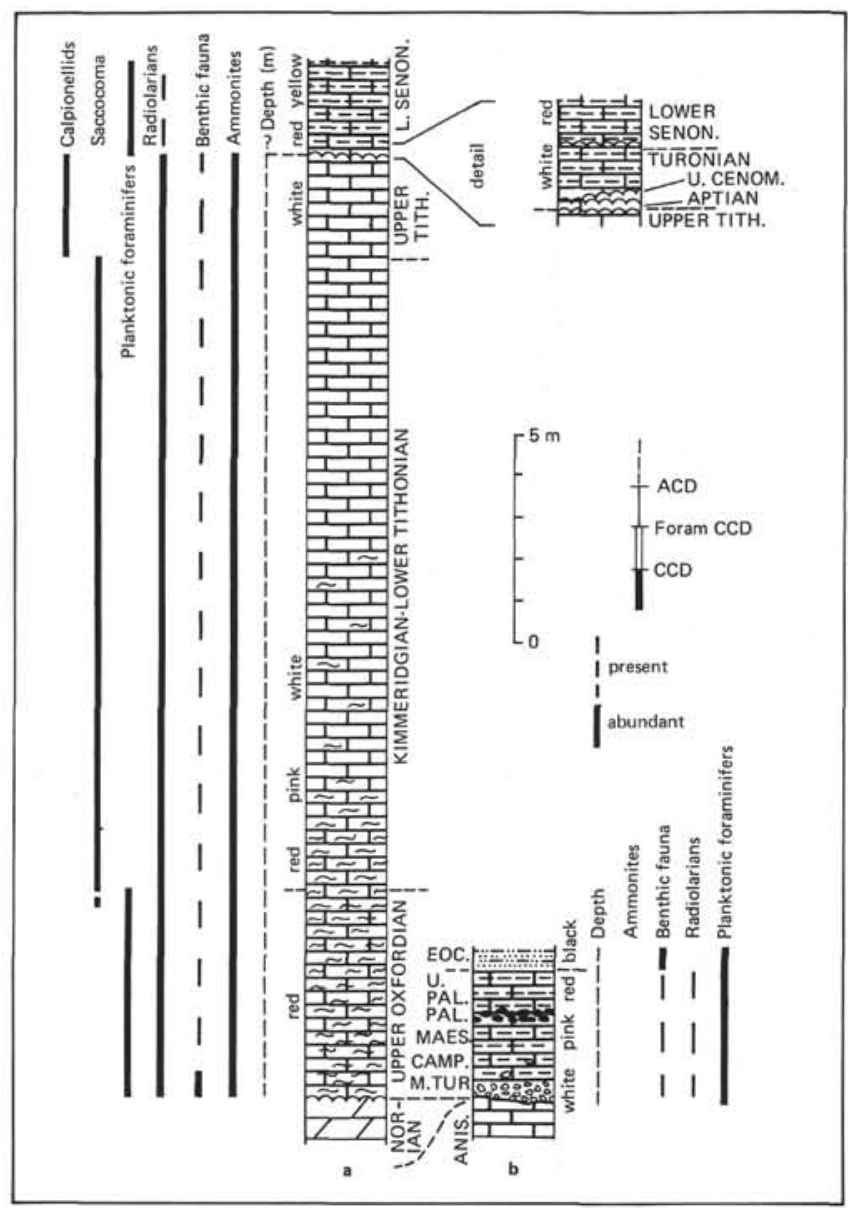

Figure 9. Saint-Crepin (a) and La Pisse (b) sections.

The water depth of deposition was great; it was deeper than the foraminifer CCD up to the Cenomanian, and probably above the CCD after the Cenomanian.

The redox conditions were reducing during the Oxfordian to Kimmeridgian, more oxidizing until the Aptian(?), then reducing again during Aptian(?)-Cenomanian, and finally somewhat oxidizing during Late Cretaceous time.

\section{Soureliou Section (Figure 8)}

The Upper Jurassic and Lower Cretaceous sediments are almost pure radiolarian limestones rhythmically interbedded with calcarenites; some of these calcarenites also contain ammonites, gastropods, and bivalves. The limestones are associated with early diagenetic cherts which had been lithified earlier than the calcareous material (Plate 4, Figure 3).

The Albian-Cenomanian beds consist of alternating radiolarian cherts and completely azoic black claystone and siltstone.

This succession of facies suggests that the Soureliou section was probably deposited at water depths beneath the foraminifer CCD up to the Albian, and beneath the total CCD up to the Maestrichtian. The uplift of the bottom above the CCD during the Maestrichtian was one of the first local signs of the Alpine orogenic compression.

There is doubt about the depth of the sea floor during the late Tithonian-Berriasian because of the existence of a cal- 


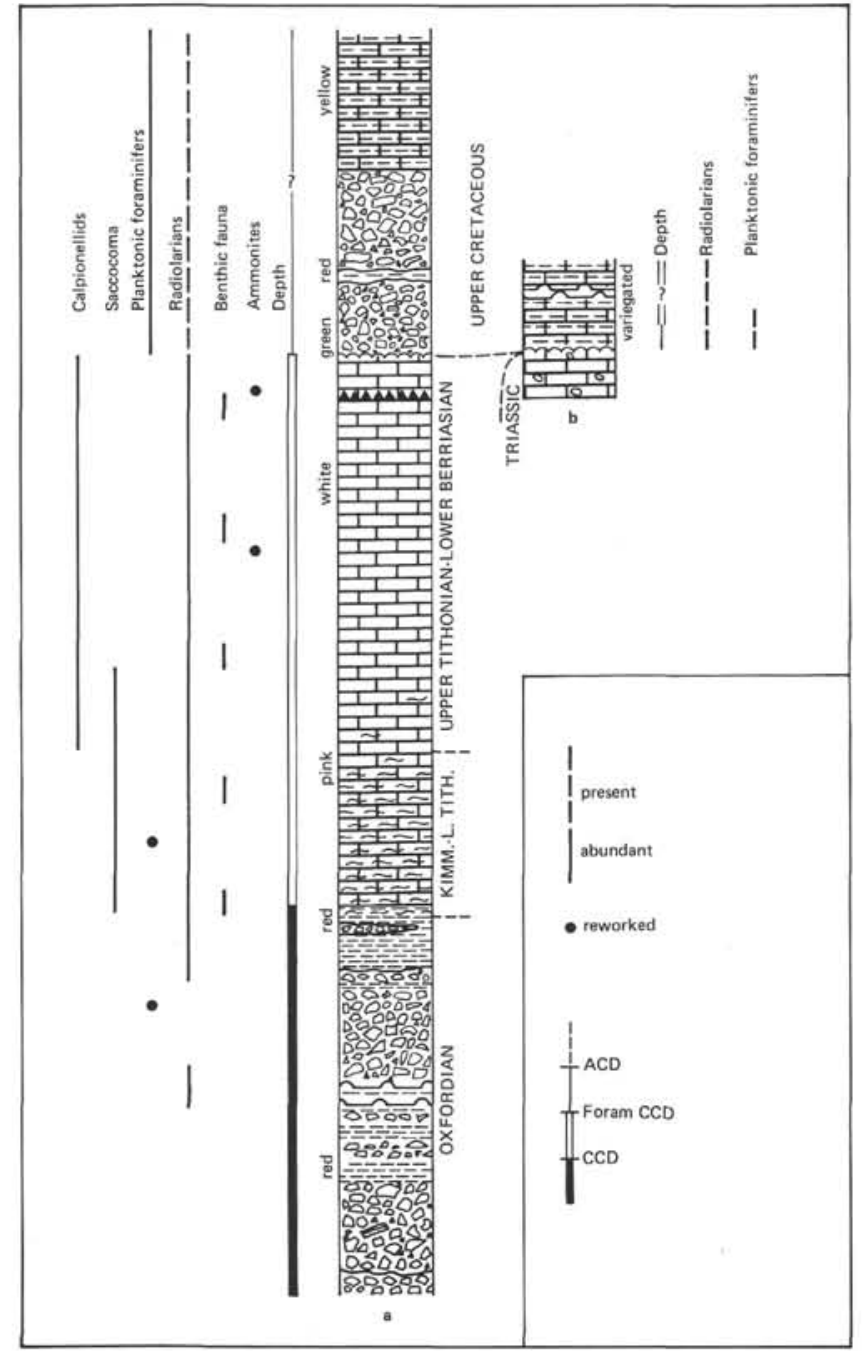

Figure 10. Southern ( $a$ ) and northern (b) Queyrellin sections.

pionellids layer and, particularly, of a layer of ammonites and gastropods. These organisms could have been carried seaward and quickly buried in water below the aragonite compensation depth. Alternatively, if we suppose that they were not transported, we must infer that the carbonate compensation levels were deeper at the time of deposition.

The rate of sedimentation is extraordinarily low: about 20 meters from the Kimmeridgian to the Aptian or the Albian (i.e., about $20 \mathrm{~m}$ for $45 \mathrm{~m}$.y. equals $0.5 \mathrm{~mm}$ per 1000 years, without taking the compaction into account). Extremely low sedimentation rates could have resulted from deposition in great water depths or because the Briançonnais realm was, on a large scale, only a zone of transitional slopes between the continent or an epicontinental sea (Subalpine zone) and the deep oceanic bottoms (Piémont zone) and thus very unstable.

Isotopic analysis $\left(\mathrm{C}^{12 / 13}, \mathrm{O}^{16 / 18}\right)$ were made systematically on these sediments. These are interpreted by Létolle et al. (this volume).

\section{La Pisse Section (Figure 9)}

The sedimentary sequence is much condensed in the La Pisse section. For example, only 1.5 meters comprise the middle Turonian to the Maestrichtian stage. Sedimentation rates are, then, about $0.05 \mathrm{~mm}$ per 1000 years, without accounting for compaction (Plate 4, Figure 1).

Two gaps in sedimentation occur. The lowest gap covers a very long period from the middle Triassic to the early Turonian, and was caused by various conditions. The Briançonnais emerged during the upper Lias (see discussion above) and the upper Triassic, missing here, was eroded during that time. But during the Middle Jurassic (Bathonian), the Briançonnais was immersed again and thus the remainder of the gap must be attributed to non-deposition in a marine environment. This non-deposition was caused either by the action of bottom currents, or because the slope of the marine bottom was so great that sediments could not be deposited (Middle-Upper Jurassic, Lower Cretaceous).

The second gap in sedimentation occurred at the end of Late Cretaceous and beginning of the Paleocene and is marked by a layer of metallic ( $\mathrm{Fe}, \mathrm{Mn})$ and phosphatic nodules. This gap is probably a result of bottom current activity.

The fauna of the La Pisse section consists mainly of planktonic foraminifers. Recrystallization has totally obscured any traces of nannofossils which probably were present in the sediment. The Paleocene nodules have foraminifer-generated concentric crusts similar to those described by Wendt (1974).

The components of the breccia are Triassic limestone and dolomite; the breccia probably was formed when synsedimentary fault-scarps collapsed during late Cenomanian-Turonian times.

From the middle Turonian to the late Paleocene, the depositional environment seems to have been rather well oxygenated and subjected to current activity (deposition of red limestone, gaps in sedimentation with formation of metallic oxide nodules). Thus, the site was probably relatively high, and in particular, was higher than the Cuchon and Soureliou sections.

The sediments were probably deposited in a water depth between several hundreds of meters and the foraminifer $\mathrm{CCD}$, but we cannot determine the precise depth with greater precision. Nevertheless, the Paleocene calcareous nodules are similar to the Recent nodules collected from about a thousand meters depth on the Blake Plateau (Pratt and MacFarlin, 1966; Monty, 1973).

\section{Saint-Crepin Section (Figure 9; Plate 4, Figure 2)}

Because of its similarity with the La Pisse section we will not deal in detail with the Saint-Crepin section. Note, however,

1) the presence of a nodular Upper Jurassic limestone with ammonites and gastropods (along with calpionellids, Saccocoma, and planktonic foraminifers) which indicates deposition at a depth shallower than the ACD.

2) a gap in the Lower Cretaceous sequence marked by a hard ground and a phosphatic crust which suggests deposition in rather shallow water.

3) that the base of the Upper Cretaceous foraminifernannofossil (?) clayey limestone comprises three very thin units separated by hard grounds dated,respectively, as Aptian, upper Cenomanian, and Turonian. These hard grounds were probably formed by currents. 
4) the depositional environment was probably about the same as that of the La Pisse section, but the region may have been topographically higher and thus may not have received any Triassic carbonate fragments.

\section{Queyrellin Section (Figure 10)}

In the Queyrellin section the Oxfordian breccias, siltstones, and radiolarian cherts lie directly on the middle Triassic platform carbonates and breccias. (The two sections [northern and southern] shown in Figure 10 are a few hundred meters from each other.) The gap in sedimentation, as is the case for the La Pisse section, is the result of continental erosion during Liassic emergence of the Briançonnais domain, and of submarine non-deposition at the end of the Middle Jurassic and beginning of the Late Jurassic. The Middle-Upper Jurassic unconformity appears similar to the Saint-Crepin unconformity but no phosphatic hard-ground is associated with it in the Queyrellin section. In the northern section, the Upper Jurassic is absent and the two gaps merge.

The fauna in the nodular limestone comprises Saccocoma, calpionellids and Aptychus. The presence of radiolarite, silt, and clay at the base of the series and the absence of ammonites in the limestone reveal that it was probably first deposited in water deeper than the $\mathrm{CCD}$, then later at a depth between CCD and ACD. The unit was deposited in a rather oxygenated environment (red radiolarite and shale and red limestone).

The number and the thickness of the breccias suggest that they were deposited in an unstable zone of very irregular topography. Thus, the morphology of the sea floor could have offered in neighboring places (1) gentle and rather low areas where sediments could be deposited and (2) steeper sloped mounts where sediments could not accumulate. The breccias are clearly restricted to two zones: (1) the base of the Upper Jurassic and (2) the upper Cenomanian-lower Senonian.

\section{Piemont Zone (Figure 11)}

The palinspastic distance between the Briançonnais and the section is about one hundred kilometers. Moreover, the outcrop occurs in a fully metamorphosed zone which makes a normal sedimentological study impossible. We can only note that the marine bottom probably subsided concurrently with the depression of the CCD as time passed (Bosellini and Winterer, 1975). During Late Jurassic time, two types of sediments were deposited: radiolarites, below the CCD, followed by limestones, perhaps following a depression of the $\mathrm{CCD}$ which occurred more rapidly than subsidence of the marine bottom. During Early Cretaceous time, the marine bottom was again below the CCD, and siltstone, shale, and calcarenite were deposited.

The rate of sedimentation cannot be determined, but it was probably slow. The white Upper Jurassic limestone must have been deposited in a slightly oxygenated environment, while the siltstone, claystone, and calcarenite of the Lower Cretaceous were perhaps deposited in a more restricted environment.

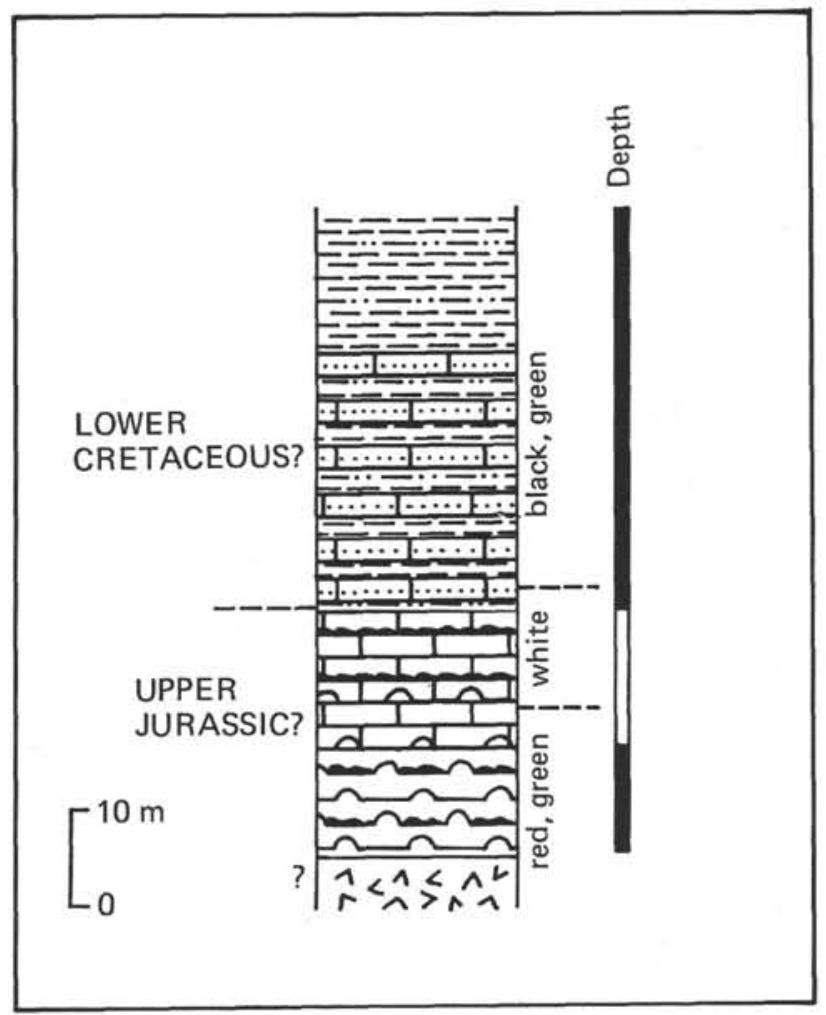

Figure 11. Piemont zone: the type of section.

\section{COMPARISON OF THE WESTERN NORTH ATLANTIC AND NORTH TETHYAN MARGINS}

Facies

\section{Nodular Red Clayey Upper Jurassic Limestone}

\section{(Ammonitico Rosso)}

The lower Tithonian red clayey limestone from Hole 391C is an example of the nodular red clayey faces. It is not completely recrystallized and has some red and green zones with indistinct contacts (Plate 5, Figure 1). The Briançonais Upper Jurassic limestone, to which it compares, has been submitted to a long and intense diagenesis and the nodular aspect has been emphasized by slight metamorphism. White limestone nodules are well defined in a calcareous, clayey, and iron-rich red matrix(Plate 5, Figures 2 and 3). Many signs show clearly that the white nodules and their red matrix were lithologically similar when deposited (Plate 5, signs show clearly that the white nodules and their red matrix were lithologically similar when deposited (Plate 5, Figure 3a, b), as has been shown by Jenkyns (1974). A strong and selective flow of water, however, leached a significant proportion of the carbonate from the matrix and may have introduced the other components (clay and iron-oxides). Microprobe analysis has shown that the Upper Jurassic red zones of the Blake-Bahama Basin sediments were slightly richer in iron and clay than the green or gray zones. This difference may have resulted either because the two matrixes were originally different, or, more probably, because they were subjected to two different diagenetic processes. 
As for the sedimentation depth, the Blake-Bahama Basin might have been comparable to the Queyrellin area, whereas the Saint-Crepin area and the Subalpine realmwere probably much shallower.

\section{White Homogeneous Limestone (Upper Tithonian-Berriasian)}

The white Tithonian-Berriasian limestone is certainly the most prevalent facies and is found in almost every studied section where the Upper Jurassic is represented. Certainly during this time period the depositional environment was very uniform in many parts of the Atlantic Ocean and the Tethyan Sea. Only the depth of deposition, relative to the $A C D$ and $C C D$, varies from place to place: the Subalpine zone and higher areas of the Briançonnais are shallower than the ACD; the Blake-Bahama Basin and lower parts of the Briançonnais and Piémont zone are deeper than the $A C D$ and often deeper than the foraminifer CCD, but the content of calcareous material (deposited or reworked and redeposited) remains about the same inducing a similarity of facies.

\section{Radiolarian-nannofossil Limestone (Lower Cretaceous)}

In spite of millimetric insertions of black shale, these limestones of the Blake-Bahama Basin are similar to those from the Subalpine zone which have been deposited at a shallower depth, and those of the Cuchon and of Soureliou sections, which contain many cherty beds. We do not know how the silica of the radiolarians disappeared or where it was redeposited, the latter having been replaced by some calcite.

\section{Lower Cretaceous 'Reef' Facies (Blake Nose)}

The Lower Cretaceous "reef" facies suggests the Urgonian facies of the Subalpine zone. The "reef" is also similar to the platform carbonates of Triassic age and to the pelletoidal, oncoidal Middle Jurassic (Briançonnais) but, in these two cases, the depositional processes were somewhat different.

\section{Cretaceous Black Shale (Blake-Bahama Basin)}

The Cretaceous black shale are similar to the black marls of the Subalpine zone, and of Cuchon and also the black siltstones and claystones (but alternating with radiolarites) or Soureliou.

\section{Nannofossil-foraminifer Ooze (Blake Nose)}

In spite of the lack of nannofossils in the Alpine section, because of recrystallization, the foraminifer-clayey Upper Cretaceous limestones of the whole Briançonnais realm may be compared with the nannofossil ooze of the Blake Nose.

\section{Sedimentary Environment}

\section{Depth}

The lowest part of the Briançonnais was deposited below the CCD at the beginning of the Late Jurassic, then above the CCD during Late Jurassic-Early Cretaceous time and once again below the CCD about at Albian time (See Figure
14). This phenomenon could be explained by three possible causes: (1) the sea bottom remained at the same level and the CCD fluctuated; (2) the CCD stayed at the same depth and the depth of the sea bottom fluctuates, and (3) the depths of both the CCD and of the bottom varied.

The third solution is the most likely one. If we assume that (a) the Briançonnais margin deepened from late Bathonian to Cenomanian time and (b) the CCD also deepened during the same period (Bosellini and Winterer, 1975), then we must conclude that the CCD deepened much more quickly during Late Jurassic time and that the CCD reached the sea bottom at about Albian time.

We do not know the nature of the Oxfordian sediments in the Blake-Bahama Basin, but we know that the sea bottom effectively reached the CCD at about Aptian-Albian time. The depth probably always remained below the CCD in the Piémont realm, except perhaps for a short period in the Late Jurassic. The depth of the Blake Nose and of the highest areas of the Briançonnais were very similar, but it is difficult to assess them.

\section{Marine Bottom Topography}

The Blake-Bahama Basin and the Blake Nose were low and high areas, respectively, during Late Jurassic and Cretaceous times as they are at present. The facies of both groups of sediments seem to confirm this relative stability. In contrast, evidences of high instability during the Late Jurassic and Cretaceous are numerous in the Briançonnais: slumped beds and also breccias originating from fault scarps. We note two paroxysmal periods: the early Late Jurassic which corresponded to a main phase of the Tethyan Sea opening, and the beginning of the Late Cretaceous (Cenomanian) which probably corresponded to the first compression of the future Alpine chain.

Numerous topographic highs and slopes resulted from these synsedimentary deformations. The mounts were probably swept by currents and did not receive any sediment. The few sediments laid down on the steeper slopes were reworked downslope toward more stable areas. Metallic nodules and crust-bearing hard grounds were formed in both cases. Slumping occurred on the more gentle slopes.

\section{Depositional Environment: Redox Potential and Currents}

Evidences of current activity and oxidizing environments seem to be closely linked. Currents were apparently active during the early Tithonian in both domains where they induced reworking and the oxygenation of the sediments (Blake-Bahama Basin, Saint-Crepin, Queyrellin), gaps in the sedimentary record, and the formation of hard grounds (Subalpine zone and overall Briançonnais). They were apparently active less frequently during the late Tithonian-early Berriasian time - particularly in the Blake-Bahama Basin and in the low regions of the Briançonnais.

Bottom currents were once more very active during the Cretaceous. They perhaps dated from the late Berriasian in the Briançonnais, from the Barremian, and certainly from the late Albian on the Blake Nose. They were responsible for many gaps in sedimentation during this time on the Blake Nose and in the Saint-Crepin and La Pisse sections. In contrast, they were apparently absent, at least during 
Aptian-Albian times, in the lowest areas where reducing conditions prevailed (deposition of the black shales). During and after the Albian, they may have been responsible for a gap in sedimentation (unconformity between the Cretaceous black shales and the Tertiary turbiditic sediments).

\section{Temperatures and Salinities}

The very complex interpretation of temperatures and salinities prevailing during deposition of these sequences, given in the companion paper (Létolle et al., this volume) does not give final results. Nevertheless, a fairly good harmony exists between the isotopic changes in the carbonates of both studied domains (in particular between the Blake-Bahama Basin and the Soureliou section). They show similarities between depositional environments in both regions.

\section{Rate of Sedimentation (Figure 12)}

The data in Figure 12 are taken partly from the Leg 44 site reports, presented in this volume (Atlantic margin), and partly from personal calculations (Tethyan margin).

We need not expect the two thickest series (Subalpine zone and Blake-Bahama Basin) to be very similar inasmuch as sediment may have accumulated under different conditions: in shallow water near the continent (Subalpine zone); in deep water and including accumulation from gravity flows in a depression supplied from almost all sides (Blake-Bahama Basin).

The extraordinarily low rate of sedimentation over such a long period for the Briançonnais has no equivalent in the sediments studied from the North Atlantic. The low rate of sedimentation in the Briançonnais is the result of current activity and because of instability caused by rough topography of the marine bottom. The Briançonnais was also a path for sediments from the continent (or an epicontinental sea) toward the ocean.

The rates of sedimentation of the Upper Cretaceous foraminifer-nannofossil ooze are very similar in the two studied domains.

\section{Rate of Subsidence (Figure 13)}

We can distinguish accelerations or apparent accelerations of subsidence in the North Atlantic and North Tethyan series. Subsidence rates can be calculated when the subsidence is equal to the thickness of the sediments (e.g., thick accumulation of shallow-water carbonates, as is the case during the Triassic in the Briançonnais domain, or during the Barremian in the Blake Nose area) and if we know how long the period of sedimentation has lasted. This is not the case on the Blake Nose where the age of the oldest "reef" facies sediments is unknown. On the other hand, we can calculate the subsidence rate during deposition of the middle and upper Triassic beds in the Briançonnais. The Norian beds were deposited at a maximum of $135 \mathrm{~mm}$ per 1000 years presuming the compaction is $2 / 3$ ( $\mathrm{J}$. Megard-Galli, personal communication).

We can also estimate the rate of subsidence when the marine bottom has deepened from sea level to near a known level (for example compensation depth or lysoclines;

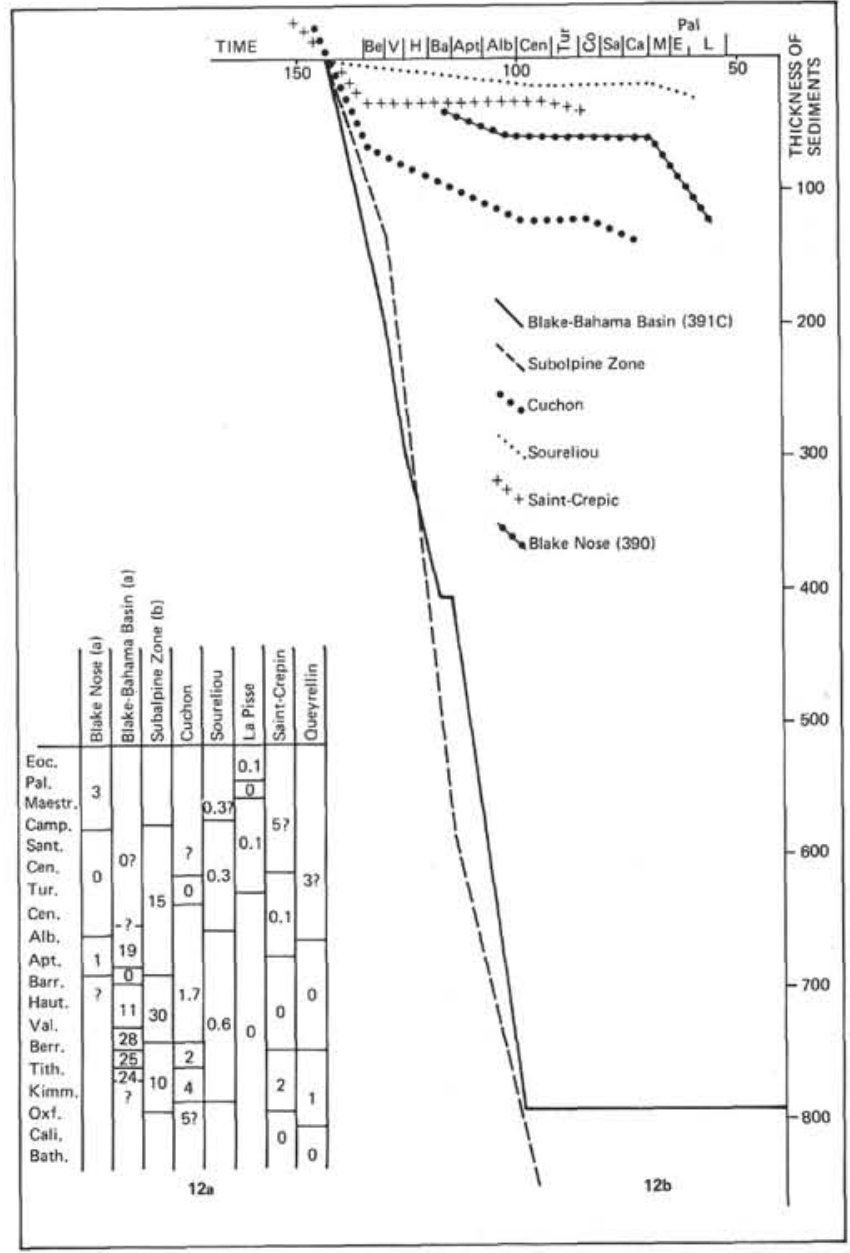

Figure 12. Rates of sedimentation.

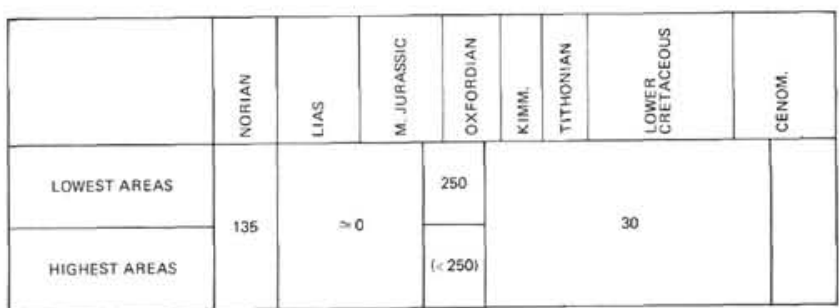

Figure 13. Rates of subsidence.

Berger, 1970, 1973; Berger and Winterer, 1974). This is the case in the Briançonnais for the subsidence phase between the Bathonian (shallow-water deposits) and the Oxfordian (deep pelagic deposits, deposited below the CCD in the lowest areas). If we assume that the CCD was 2500 meters deep during late Bathonian-early Oxfordian times (Bosellini and Winterer, 1975) and that the subsidence of the sea bottom took place during the same period, the rate of subsidence is about 2500 meters for 10 million years; i.e., $250 \mathrm{~mm}$ per 1000 years. This apparent acceleration of subsidence is not much higher than the regular rate of subsidence during Triassic time (135 mm per 1000 years). But note that because the maximum time interval is used in the calculation, $250 \mathrm{~mm}$ per 1000 years is a minimum value. The marine bottom may have subsided during only a part of 
the late Bathonian-early Oxfordian interval, and thus subsidence may have been much more rapid.

From these rates we may estimate the rate of subsidence of the Blake Nose during the Barremian, between the "reef" deposits and the nannofossil ooze. Two cases are possible: (1) the rate of subsidence was very high, much above to $250 \mathrm{~mm}$ per 1000 years, which because reef growth could not keep pace, the reef foundered and died, (2) subsidence was about $250 \mathrm{~mm}$ per 1000 years and the reef or peri-reef sediments easily kept pace with it. (In the Urgonian facies of the Subalpine zone, a rate of subsidence greater than $300 \mathrm{~mm}$ per 1000 years is known at some areas (A. Arnaud-Vanneau, personal communication). Thus, in the latter case, the reef might have died for some reason independent of the subsidence (for example, general climatic conditions which resulted in the deposition of the black shales in the depressions, or a rapid decrease of the sea-water temperature - a phenomenon which is not contrary to the isotopic analysis results (Létolle et al., this volume).

The rates of subsidence of the deep marine bottoms are difficult to estimate. The calculations for the Blake-Bahama Basin and the lowest areas of the Briançonnais depend on hypotheses concerning the carbonate compensation depths. Thus, if we assume, in agreement with Bosellini and Winterer (1975), that the CCD was 2500 meters deep during the Late Jurassic (and therefore $1500 \mathrm{~m}$ deep for the ACD) and 4500 meters deep during the Aptian-Albian, we can calculate a subsidence rate of about $30 \mathrm{~mm}$ per 1000 years during Late Jurassic and Early Cretaceous times.

\section{CONCLUSION: COMPARISON OF GEOGRAPHIC EVOLUTIONS}

The geographic evolutions for both the western North Atlantic and Tethyan margins are shown on Figure 14. We note that a common pattern of sedimentary evolution characterizes both margins. Common elements include

1) general deepening from the Oxfordian to the Cenomanian (Briançonnais), and from Barremian to the present time (Atlantic), with (a) deposition of platform carbonates, followed by (b) a gap in sedimentation marked by a hard ground (probably corresponding to very unsteady conditions during the deepening) and then (c) deposition of pelagic limestones or oozes. This is the case for the Blake Nose during the Barremian and for the Briançonnais at the beginning of the Late Jurassic. As previously noted, this succession of facies seems to be either the result of acceleration of subsidence, or variations of the depositional conditions such as bottom topography, temperature, and redox conditions.

2) strong similarities of facies which reflect very similar environmental conditions. For example, the Tithonian and Berriasian environment was rather oxidizing; a slow evolution to more reducing conditions followed and reached a maximum in Aptian-Albian-Cenomanian times; oxidizing conditions finally reappeared during the Late Cretaceous; on the Tethyan side, the currents were very active in the highest areas with possible upwellings (as is shown by phosphatic crusts in high areas of the Briançonnais).
The main differences are

1) the marine bottom of the North Tethyan margin was very unstable which caused very complex morphology including (a) high areas where the depositional environments were similar to those of the Blake Nose; (b) low areas, on continental crust, which did not have true equivalents in the North Atlantic margin (but where the depositional environments were similar to those of the Blake-Bahama Basin; and (c) the occurrence of deposition of breccias, and slumps in two maxima: at the beginning of the Late Jurassic (linked to the opening of the Tethys) and during the Cenomanian (the beginning of the Alpine compression phase).

2) the deepening of the North Atlantic margin continues after the Cretaceous, whereas in the Alpine region it probably stopped after the Cenomanian.

\section{ACKNOWLEDGMENTS}

I thank the Deep Sea Drilling Project and especially W.E. Benson and R.E. Sheridan for offering me the opportunity to work on the Leg 44 sediments and for allowing additional sampling at the DSDP East Coast Repository at Lamont-Doherty Geological Observatory. I also thank the Centre National pour l'Exploitation des Océans-Centre Océanologique de Bretagne, and especially G. Pautot, for the financial support.

I am also grateful to D. Bernoulli, P. Ch. de Graciansky, M. Lemoine, and L. Pastouret for their good advice and profitable discussions. Thanks are also due to H. Arnaud, A. ArnaudVanneau, P.Y. Chenet, G. Deroo, M. Hoffert, J. Megard-Galli, M. Renard, and R. Létolle for providing much information and discussion during this work, and to P. Worstell for coordination with other research workers.

\section{REFERENCES}

Beaudoin, B., Campredon, R., Cotillon, P., and Gigot, P., 1975. Alpes méridionales françaises. Reconstitution du bassin de sédimentation. Excursion 7: Ninth Internat. Cong. Sedimentol., Nice.

Berger, W.H., 1970. Planktonic foraminifera: selective solution and the lysocline: Mar. Geol., v. 8, p. 111-138. 1973. Deep-sea carbonates: evidence for a coccolith lysocline: Deep-Sea Res., v. 20, p. 917-921.

Berger, W.H. and Winterer, E.L., 1974. Plate stratigraphy and the fluctuating carbonate line: Spec. Publ. Int. Assoc. Sediment., v. 1 , p. $11-48$

Bernoulli, D., 1972. North-Atlantic and Mediterranean Mesozoic facies: a comparison. In Hollister, C.D., Ewing, J.I., et al., Initial Reports of the Deep Sea Drilling Project, Volume 11: Washington (U.S. Government Printing Office), p. 801-871.

Bernoulli, D., and Jenkyns, H.C., 1974. Alpine, Mediterranean, and Central Atlantic Mesozoic facies in relation to the early evolution of the Tethys. In Dott, R.H. and Shaver, R.H. (Eds.): Soc. Econ. Palaeontol. Mineral., Spec., Publ., 19, p. 129-160.

Bosellini, A., and Winterer, E.L., 1975. Pelagic limestone and radiolarite of the Tethyan Mesozoic: A genetic model: Geology, p. 279-282.

Bourbon, M., Graciansky, P.C. de, Megard-Galli, J., and Lemoine, M., 1973. L'évolution paléogéographique du domaine briançonnais au Mesozoique: carbonates de plateforme subsidente, révolution du Lias supérieur, instauration progressive d'un régime pélagique profond: C.R. Acad. Sci. Paris, v. 277, p. 769-772. 


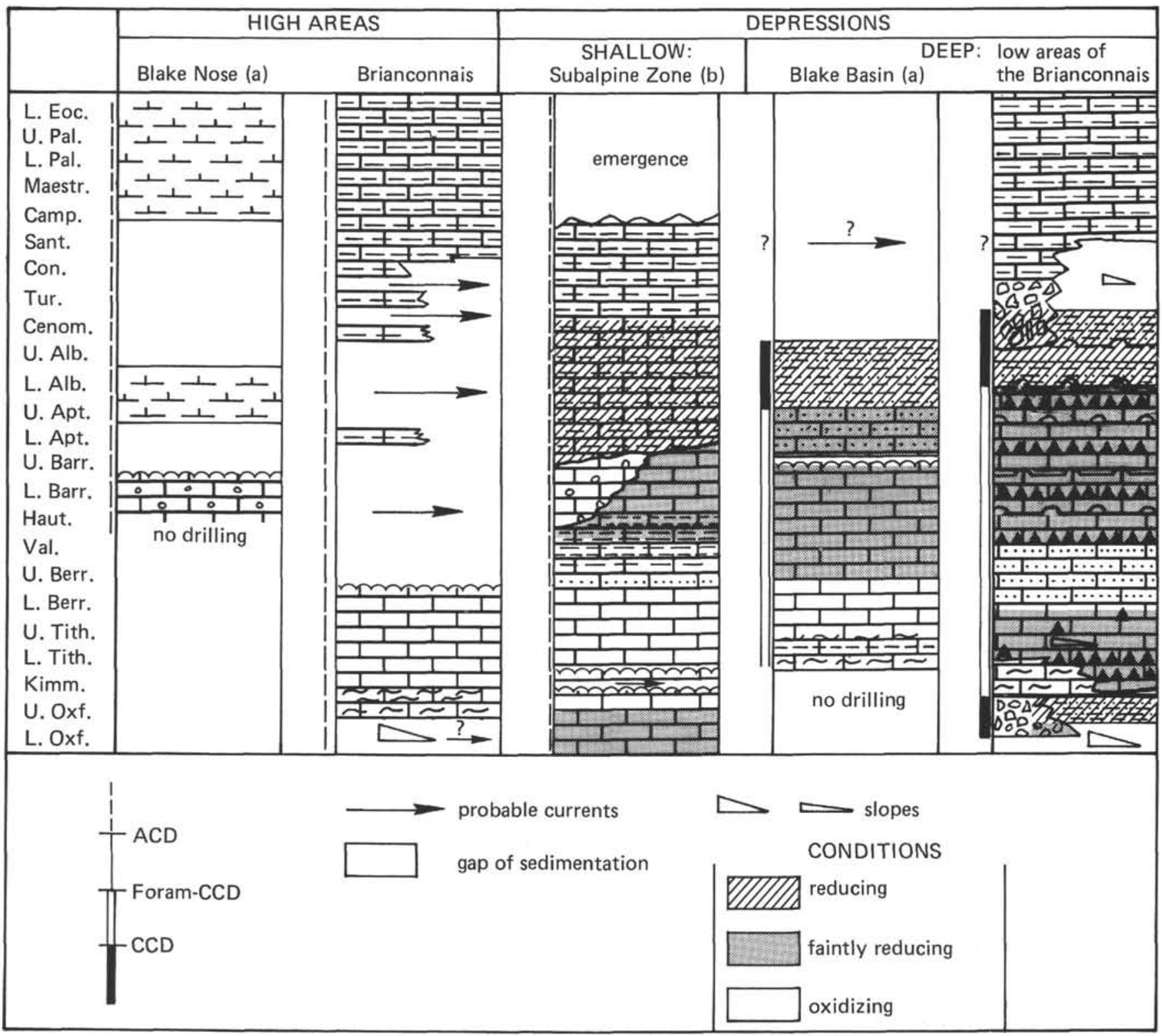

Figure 14. Paleogeographic evolutions of both margins.

Bourbon, M., Graciansky, P.C. de, Lemoine, M., Megard-Galli, J., and Mercier, D., 1975. Carbonates de plate-forme et séries pélagiques condensées dans le Mésozoique de la zone briançonnaise (Alpes françaises). Excursion 5: Ninth Internat. Congr. Sedimentol., Nice.

Jenkyns, H.C., 1974. Origin of red nodular limestones (Ammonitico Rosso, Knollenkalke) in the Mediterranean Jurassic: a diagenetic model: Spec. Publ. Int. Assoc. Sediment., v. 1, p. 249-271.

Lancelot, Y., Hathaway, J.C., and Hollister, C.D., 1972. Lithology of sediments from the Western North-Atlantic, Leg XI,
Deep Sea Drilling Project. In Hollister, C.D., Ewing, J.I., et al., Initial Reports of the Deep Sea Drilling Project, Volume 11: Washington (U.S. Government Printing Office), p. 901951.

Monty, C., 1973. Les nodules de manganèse sont des stromatolithes océaniques: C.R. Acad. Sci. Paris, v. 276, p. $3285-3288$.

Pratt, R.M., MacFarlin, P.F., 1966. Manganese pavements on the Blake Plateau: Science, v. 151, p. 1080-1082.

Wendt, J., 1974. Encrusting organisms in deep-sea manganese nodules: Spec. Publ. Int. Assoc. Sediment, v. 1, p. 437-447. 


\section{PLATE 1}

Figure 1 Bioturbations in a radiolarian limestone; the radiolarians are replaced by calcite. Lower Tithonian. Sample 44-391C-47-1, $86 \mathrm{~cm}$; thin section, $\times 8$.

Figure 2 Bioturbations and "cloudy" facies in a radiolarian limestone; the radiolarians are replaced by calcite. Valanginian-Hauterivian. Pierre-Mont section, Subalpine zone, French Alps; thin section, $\times 6$.

Figure 3 "Cloudy" facies in a radiolarian limestone: bioturbations and reworking. The radiolarians are replaced by calcite and partially filled; they do not always show geopetal structures of identical direction. Upper Valanginian-lower Barremian. Sample 44-3-391C$17-1,86 \mathrm{~cm}$; thin section, $\times 16$.

Figure 4 "Cloudy" facies in a radiolarian limestone; the radiolarians are replaced by calcite. Kimmeridgianlower Tithonian. Cuchon section, Briançonnais, French Alps; thin section, $\times 12$.

\section{PLATE 2}

Figure 1 Radiolarian limestone and a layer of accumulated radiolarians; the radiolarians are replaced by calcite. Upper Berriasian-lower Valanginian. Sample 44$391 \mathrm{C}-25-3,67 \mathrm{~cm}$; thin section, $\times 9$.

Figure 2 Clayey limestone, with thin layers of accumulated radiolarians and fish skeleton debris. Aptian. Sample 44-391C-12-3, $4 \mathrm{~cm}$; thin section, $\times 17$.

Figure 3 Faintly laminated radiolarian limestone with a layer of echinoderm pieces. Kimmeridgian-lower Tithonian. Cuchon section, Briançonnais, French Alps; thin section, $\times 7$.

Figure $4 \quad$ Top: slumped alternance of calcareous mudstone and microbreccia (benthic fauna, pebbles of Triassic dolomites and limestones) Middle: faintly laminated radiolarian limestone; the radiolarians are replaced by calcite Base: calcareous mudstone. Kimmeridgianlower Tithonian. Cuchon section, Briançonnais, French Alps; thin section, $\times 4.5$. 


\section{PLATE 1}
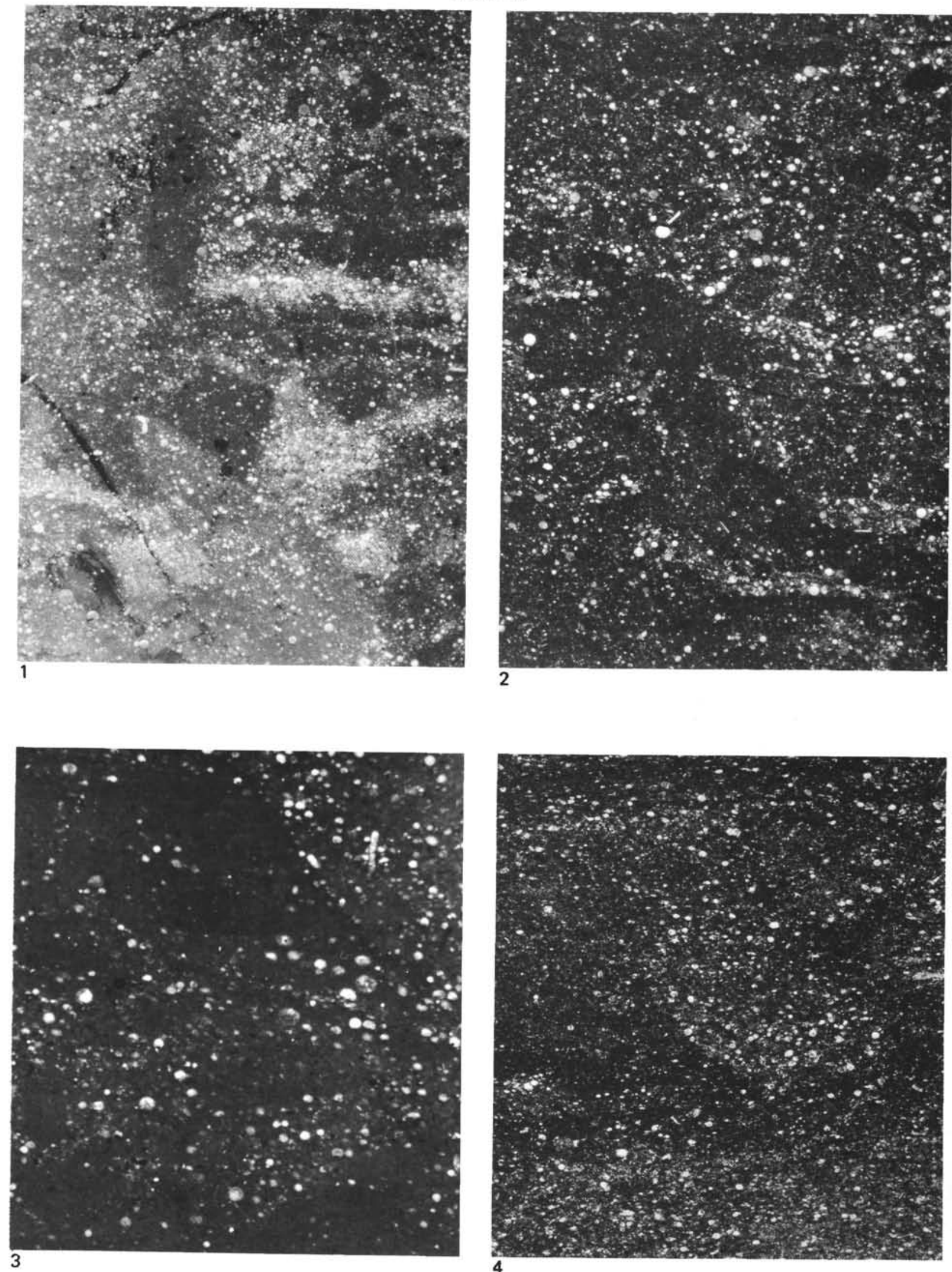
PLATE 2

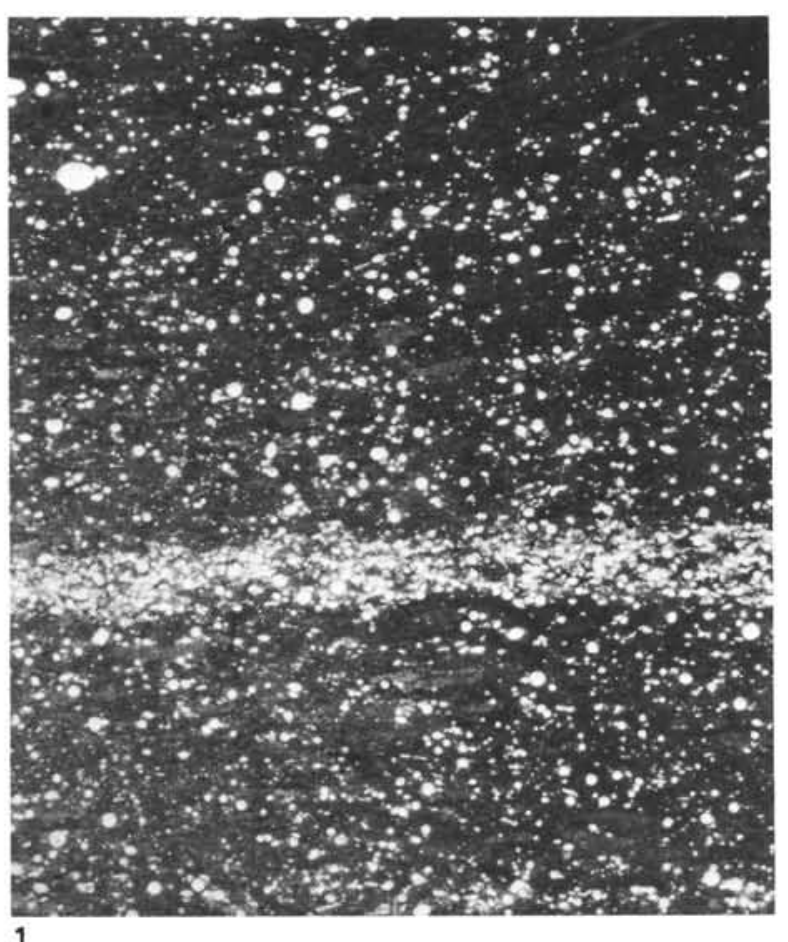

1
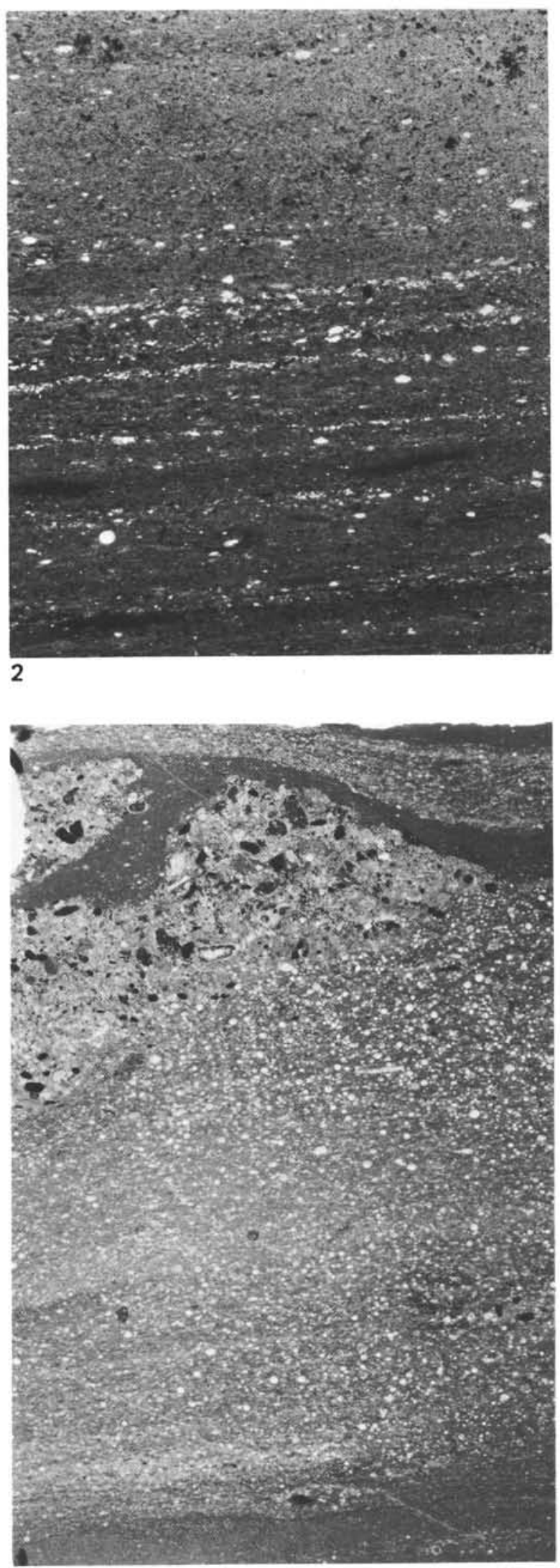


\section{PLATE 3}

"Variegated clay" in Aptian-Albian beds: the irregularity of the beds and lenses of different grain-size is due to reworking (and/or bioturbations?).

Figure 1 Upper Aptian-lower Albian. Sample 44-391C-10-2, $39 \mathrm{~cm}$; thin section, $\times 13$.

Figure 2 Upper Albian. Sample 44-391C-5, CC, $17 \mathrm{~cm}$; thin section, $\times 8$.

(see p. 966)

\section{PLATE 4}

Figure 1 La Pisse section, Briançonnais, French Alps.

a. Anisian calcareous beds.

b. Breccias, with Triassic pebbles and pelagic clayey limestone cement: middle Turonian.

c. Pelagic white clayey limestone: middle Turonian.

d. Pelagic pink clayey limestone: Campanian.

e. Pelagic red clayey limestone: Maestrichtian.

f. Conglomerate of Mn-Fe-P nodules: Paleocene.

g. Pelagic red clayey limestone: upper Paleocene.

Figure 2 Saint-Crepin section, Briançonnais, French Alps.

a. Pelagic Tithonian limestone.

b. Sharp contact and hard ground.

c. Pelagic red, green, and white clayey limestone (Aptian, Cenomanian, Turonian, and lower Senonian).

Figure 3 Soureliou section, Briançonnais, French Alps. Slumped and disrupted cherty beds in a calcareous matrix; upper Tithonian. 
PLATE 3
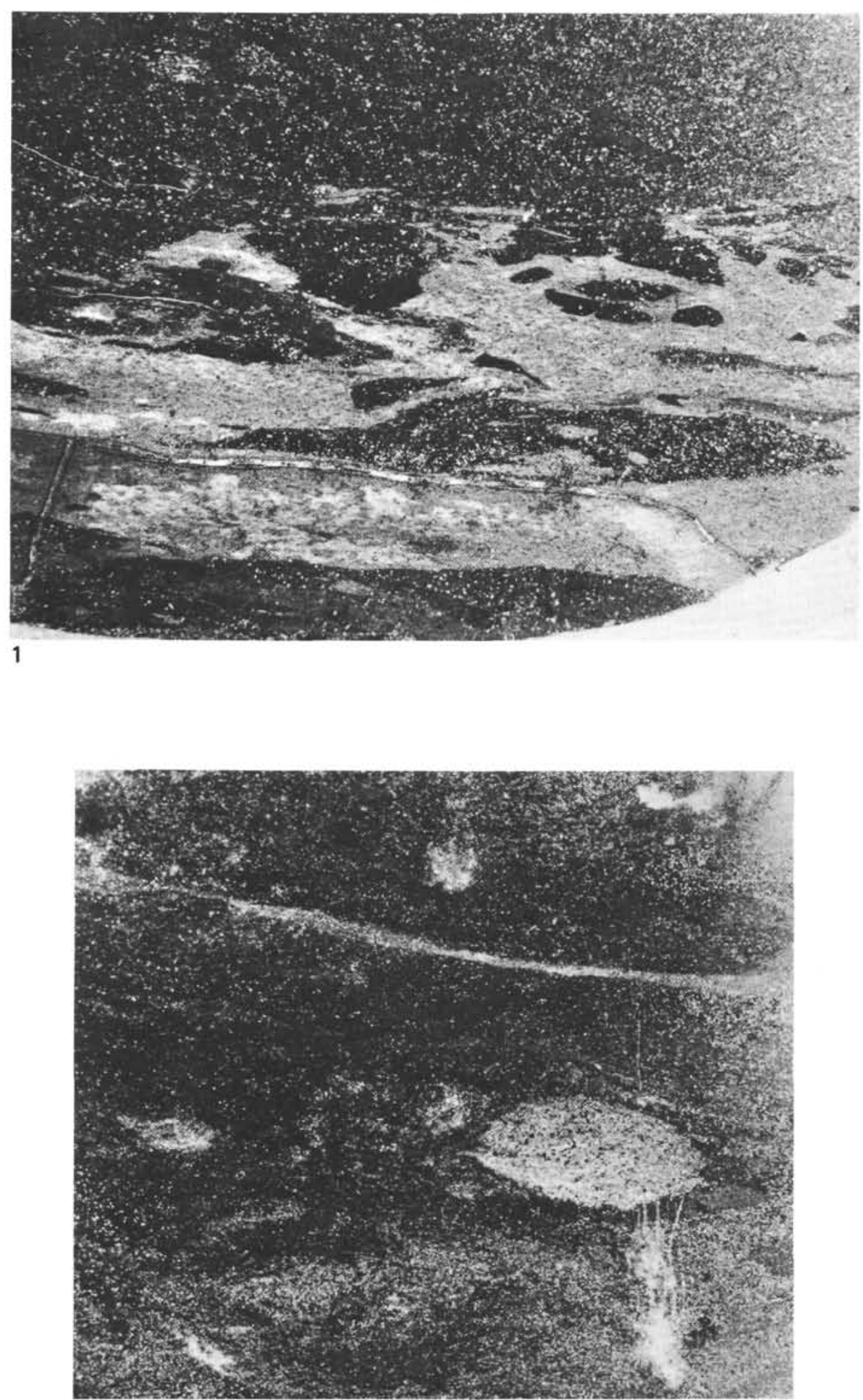

2 
PLATE 4
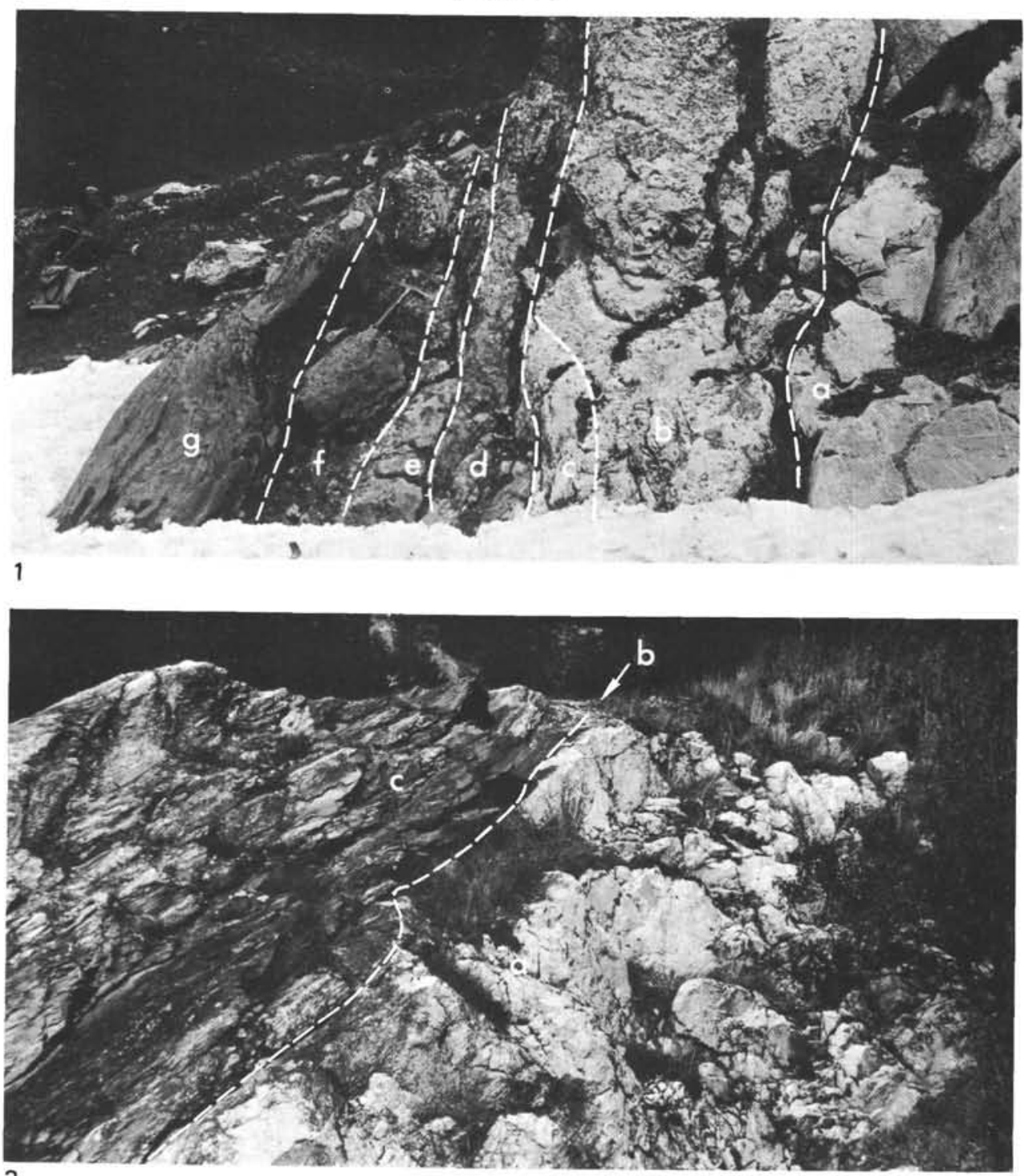
2

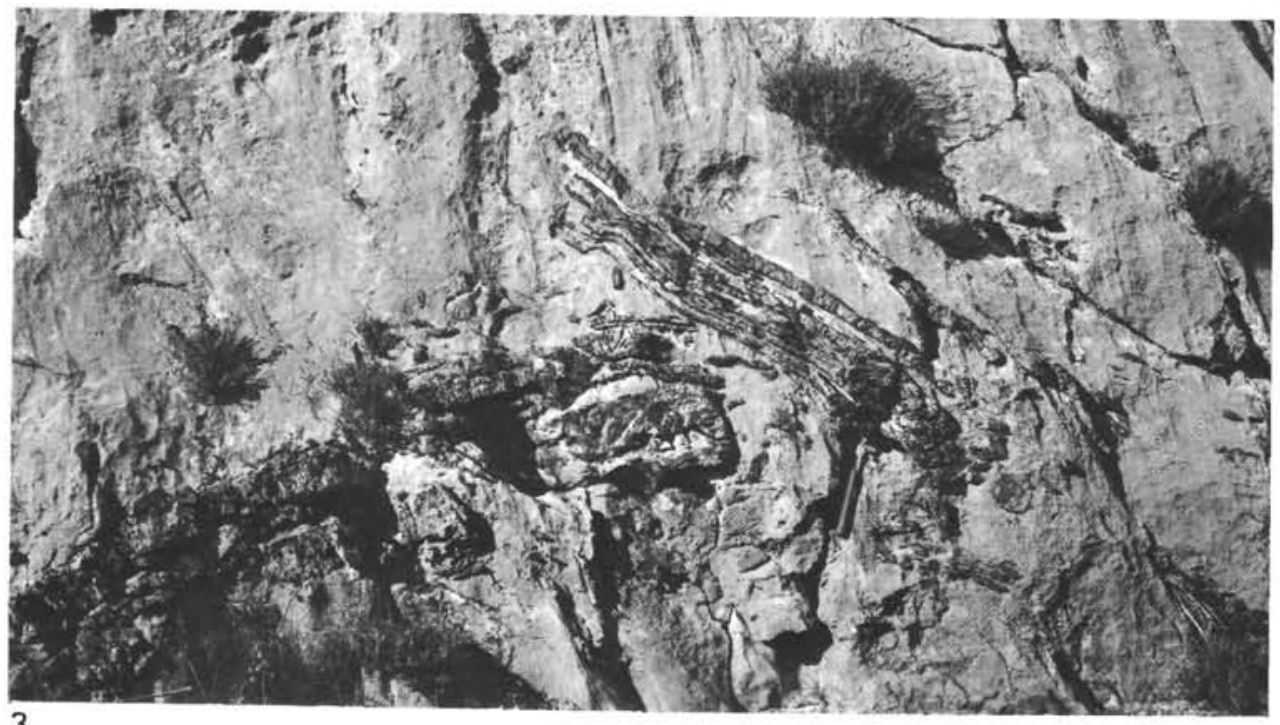




\section{PLATE 5}

Figure 1 Red clayey limestone: the dark (red) zones are rather poor in fauna (radiolarians); the transition between the dark and light colored zones is blurred. Upper Tithonian. Sample 44-391C-46-1, $129 \mathrm{~cm}$; thin section, $\times 4$.

Figure 2 Red nodular limestone: the dark (red) zones are rather poor in fauna and show a "washed" facies. The limit between the dark and light colored zones is a little more distinct than in Figure 1. Upper Oxfordianlower Kimmeridgian. Roche-Chevalière, Briançonnais, French Alps; thin section, $\times 7$.

Figure 3 Red nodular limestone: the nodular facies is here very characteristic with sharp contacts between dark red clayey and ferruginous zones on the one hand, and light colored calcareous zones on the other. Nevertheless, we can note in (a) and (b) lateral transition between the two types of zones. Note also the crystallization of calcite along the red zones. Upper Oxfordian-lower Kimmeridgian. Saint-Crépin, Briançonnais, French Alps; thin section, $\times 8$. 
PLATE 5
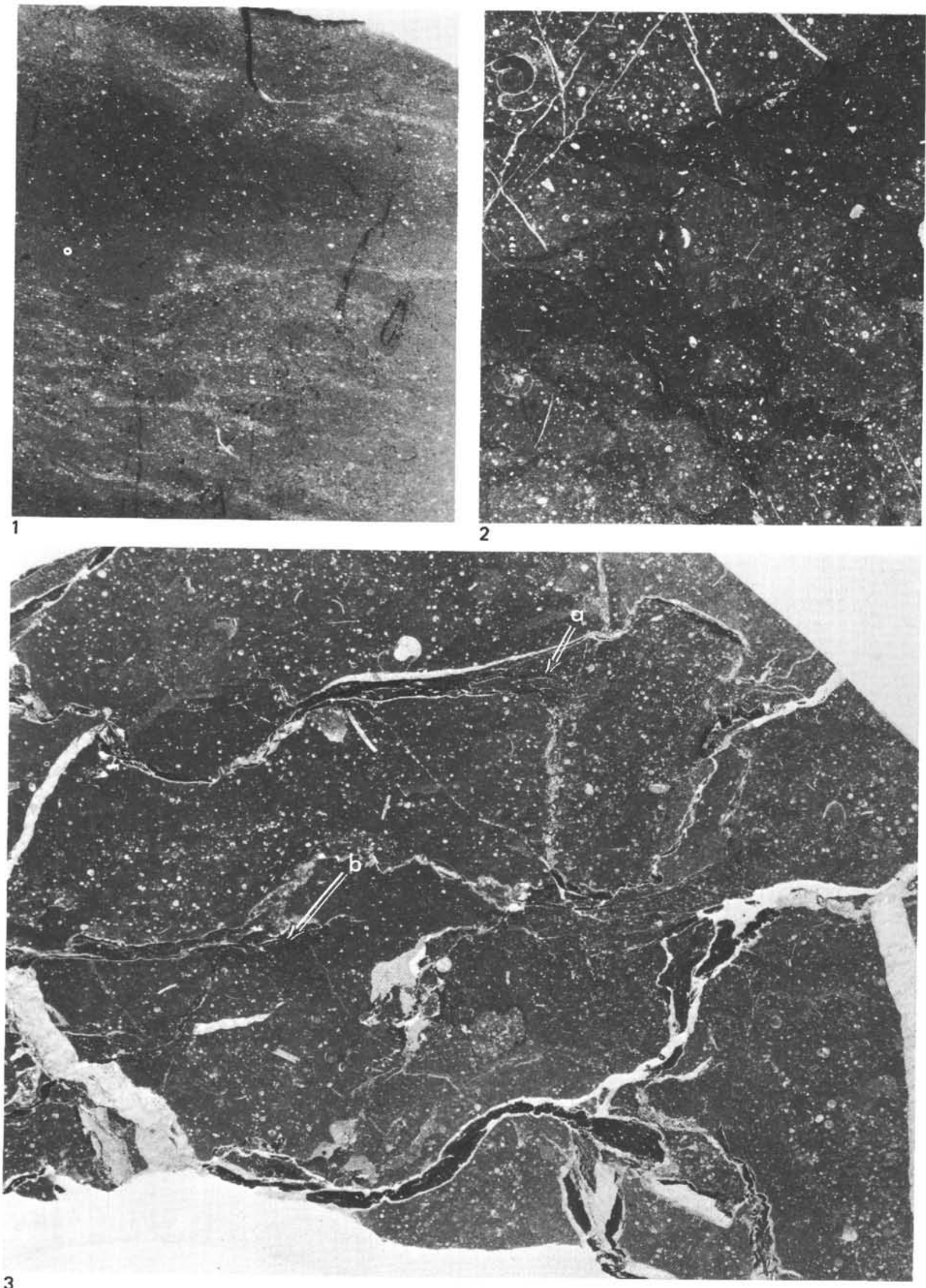